\title{
Towards inclusive funding practices for early career researchers
}

\section{$\underline{\text { Charlotte M. de Winde }}^{1,2}, \underline{\text { Sarvenaz Sarabipour }}^{3}, \underline{\text { Hugo }}$

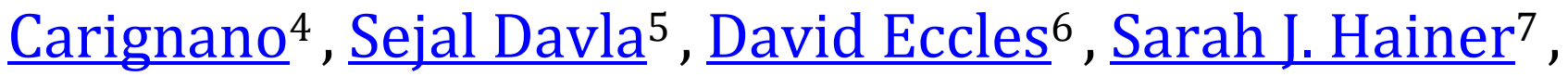 Mansour Haidar $^{8}$, Vinodh Ilangovan ${ }^{9}$, Nafisa M. Jadavji $^{10,11}$, $\underline{\text { Paraskevi Kritsiligkou }}^{12}$, Tai-Ying Lee ${ }^{13}, \underline{\text { H. Freyja }}$ Ólafsdóttir ${ }^{14}$}

${ }^{1}$ MRC Laboratory for Molecular Cell Biology, University College London, London, United Kingdom 2Department of Molecular Cell Biology \& Immunology, Amsterdam UMC location VUmc, Amsterdam, The Netherlands

${ }^{3}$ Institute for Computational Medicine, Department of Biomedical Engineering, Johns Hopkins University, Baltimore, MD

4Research Center for Agricultural and Veterinary Sciences, National Institute of Agricultural Technology (IVIT - CICVyA - INTA), Buenos Aires, Argentina

${ }^{5}$ Advanced Science Research Center, City University of New York, New York, NY

${ }^{6}$ Malaghan Institute of Medical Research, Wellington, New Zealand

${ }^{7}$ Department of Biological Sciences, University of Pittsburgh, Pittsburgh, PA

${ }^{8}$ Hasselt University, Hasselt, Belgium

${ }^{9}$ Aarhus University, Aarhus, Denmark

${ }^{10}$ Department of Biomedical Sciences, Midwestern University, Glendale, AZ

${ }^{11}$ Department of Neuroscience, Carleton University, Ottawa, Canada

${ }^{12}$ German Cancer Research Center (DKFZ), Heidelberg, Germany

13University of Oxford, Oxford, United Kingdom

${ }^{14}$ Donders Institute for Brain, Cognition and Behaviour, Radboud University, Nijmegen, The Netherlands

All authors contributed equally.

https://doi.org/10.38126/ISPG180105

Corresponding author: c.m.dewinde@amsterdamumc.nl

Keywords: funding; early career researcher; fellowship; peer-review; STEMM

\begin{abstract}
Securing research funding is a challenge faced by most scientists in academic institutions worldwide. Funding success rates for all career stages are low, but the burden falls most heavily on early career researchers (ECRs). These are young investigators in training and new principal investigators who have a shorter track record. ECRs are dependent on funding to establish their academic careers. The low number of career development awards and the lack of sustained research funding result in the loss of ECR talent in academia. Several steps in the current funding process, from grant conditions to review, play significant roles in the distribution of funds. Furthermore, there is an imbalance where certain research disciplines and labs of influential researchers receive more funding. As a group of ECRs with global representation, we examined funding practices, barriers, and facilitators to the current funding systems. We also identified alternatives to the most common funding distribution practices, such as diversifying risk or awarding grants on a partly random basis. Here, we detail recommendations for funding agencies and grant reviewers to improve ECR funding prospects worldwide and promote a fairer and more inclusive funding landscape for ECRs.
\end{abstract}




\section{Improvements to Funding Practices}
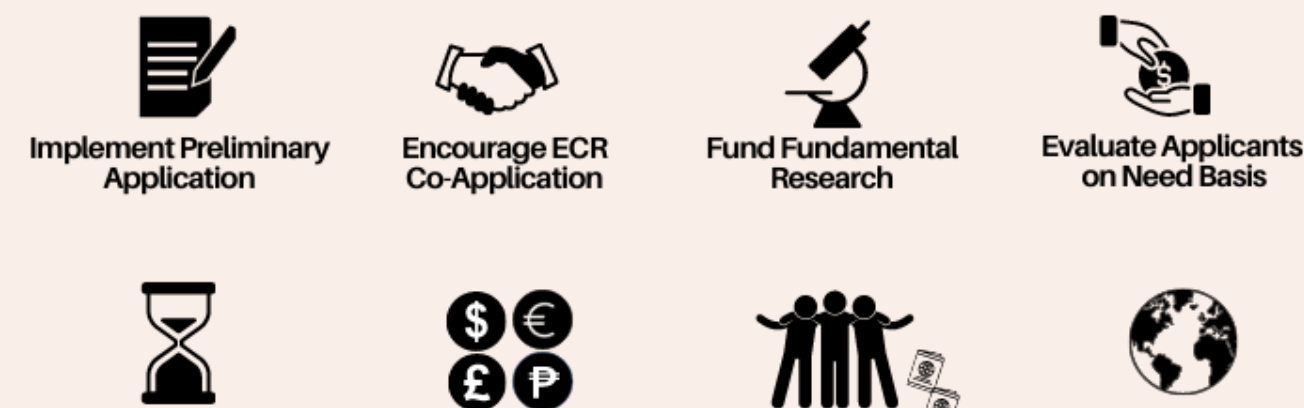

Remove time-after-PhD restrictions
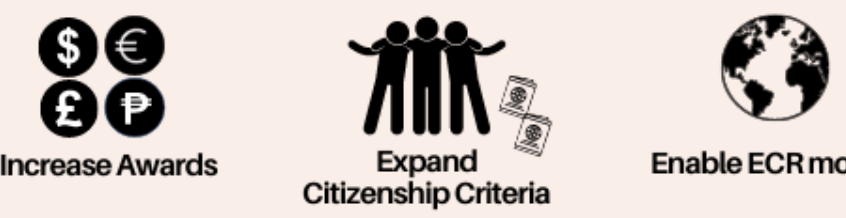

Enable ECR mobility
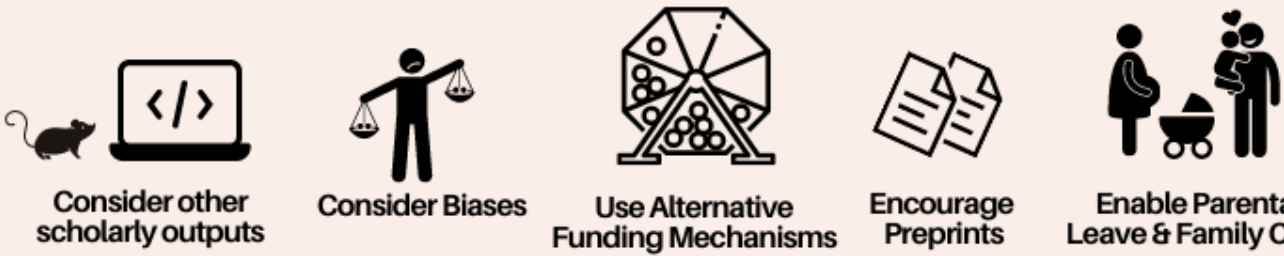

Use Alternative Funding Mechanisms

Encourage

Enable Parental Leave \& Family Care

Graphical abstract. Recommendations for fairer and more inclusive funding practices.

\section{Introduction}

The ability to obtain funding can have a significant impact on the career progression of early career researchers (ECRs) in Science, Technology, Engineering, Mathematics, and Medicine (STEMM) fields (Wright 2017; Pickett 2019; van den Besselaar and Sandström 2015). The path to an independent position is difficult for several reasons, including lengthy training time, job market saturation, and lack of sustained funding (Polka et al. 2017; FaupelBadger 2017; Fernandes et al. 2020). Obtaining research funding demonstrates the researchers' capacity for designing an independent project and building a research focus (Callier and Polka 2015). While independent funding is not a prerequisite for attaining a faculty position, there is an increasing trend that having previously secured funding is an advantage in STEMM (Pickett 2019; Fernandes et al. 2020). Furthermore, there has been a steady rise in the age at which investigators receive their first funding, and a decades-long decline in total research funding worldwide (Daniels 2015). While the number of researchers has increased in most countries (Figure 1-2), funding for ECRs is particularly low worldwide (Powell 2016, Christian et al. 2021). For example, in the US, the number of principal investigators (PIs) in their 30s or younger obtaining R01 research project grants from the National Institutes of Health (NIH) has declined from $18 \%$ in 1983 to 3\% in 2010; more than twice as many major grants are awarded to PIs who are over 65 years of age compared to those under 36 years (Rockey 2012a; 2012b; "NIH Grants \& Funding: Early Stage Investigator Policies" 2020). In the UK, the award rate for Wellcome Trust fellowships and grants has declined from $19 \%$ to $12 \%$ in the past 5 years. The cause is most likely due to there being $37 \%$ more applicants as well as a $3 \%$ decrease in the number of awards ("Wellcome Trust Grant Funding Data Report 2018/19" 2020).

The current funding landscape and a low number of career development awards can contribute to longer postdoctoral training time before securing an independent academic position. Moreover, postdoctoral contracts are often short (1-3 years), and ECRs may cycle through a number of postdoctoral positions, which limits research output as well as opportunities for ECRs to develop their ideas and establish themselves in their disciplines. 
Funding is also tight and unpredictable for junior faculty. Obtaining a tenured position is usually contingent upon securing independent external funds (Sawarkar et al. 2019; Acton et al. 2019). Beyond the lack of funding opportunities, ECRs face additional barriers that impinge on their ability to acquire research funds. These include poor mentorship, challenges in publishing, restrictive grant funding criteria, biases in grant review, and lack of feedback and transparency on outcomes of funding applications (Kuehn 2017; Shailes 2017; Tamblyn et al. 2018; Hatch and Curry 2020; "Research Assessment Practices" 2020). Importantly, these barriers do not affect all scientists equally.
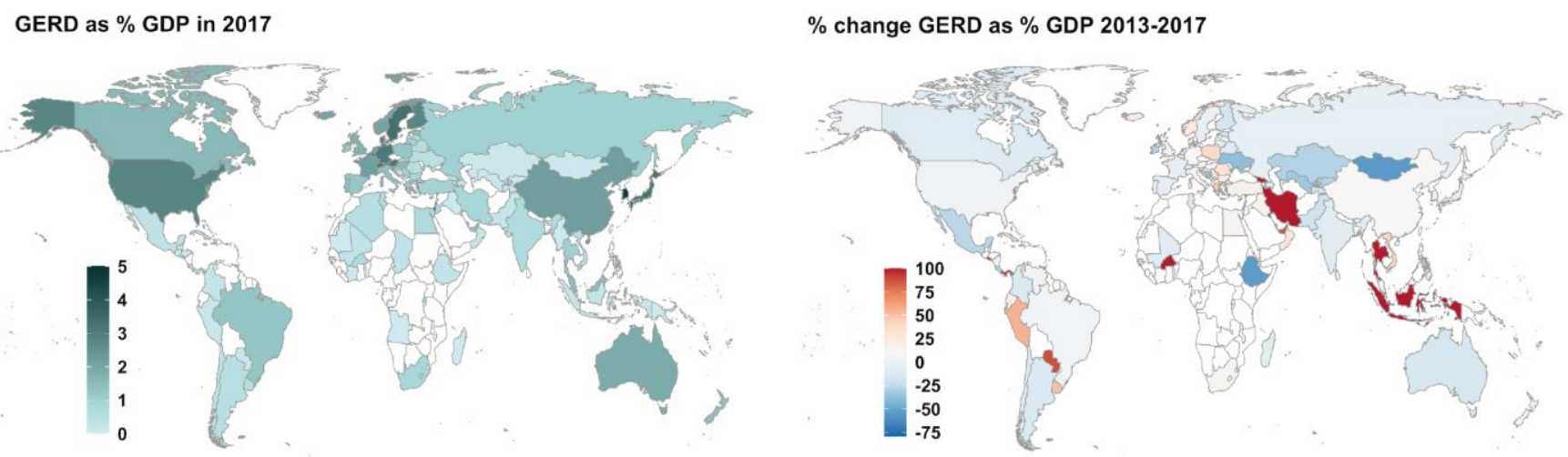

Researchers per million inhabitants in 2017

$\%$ change in researchers per million inhabitants 2013-2017
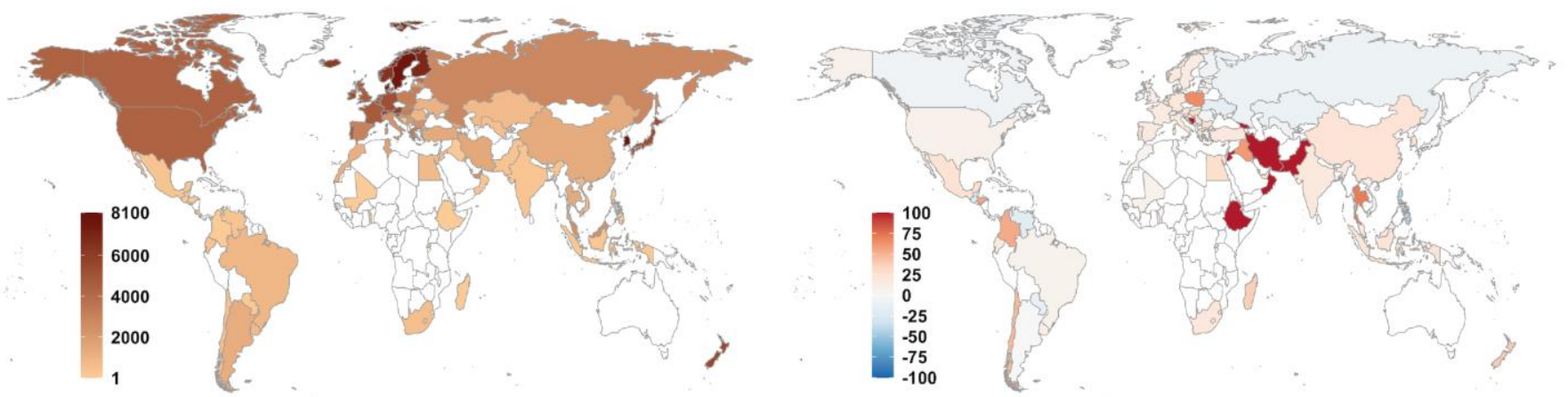

GERD per researcher in (x1000 US\$) in 2017

$\%$ change in GERD per researcher 2013-2017
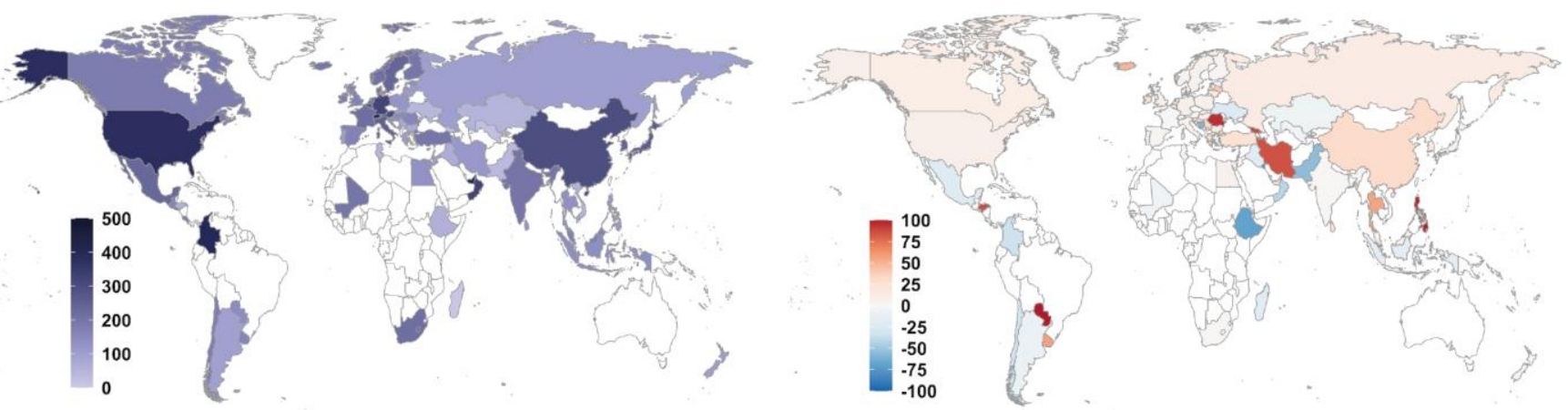

Figure 1. Human and financial resources devoted to R\&D worldwide. Latest available data (from 2017; left) on gross domestic expenditure on R\&D (GERD) as percentage of gross domestic expenditure (GDP) (top), number of researchers per million inhabitants (middle), and GERD per researcher (x1000 US\$) (bottom); and the percentage of change for each category from 2013-2017 (right). Despite the increase in the number of researchers for most countries (middle right), GERD as the percentage of GDP has decreased in most countries (top right). GERD includes expenditure on research and development by business enterprises, higher education institutions, as well as government and private non-profit organizations. Costs in local currency units were converted to US dollars (US\$) using purchasing power parity exchange rates. The white regions represent countries for which no data was available for a particular metric visualized here during 2013-2017. Data source: UNESCO Institute for Statistics (http://uis.unesco.org/en/news/rd-data-release). 


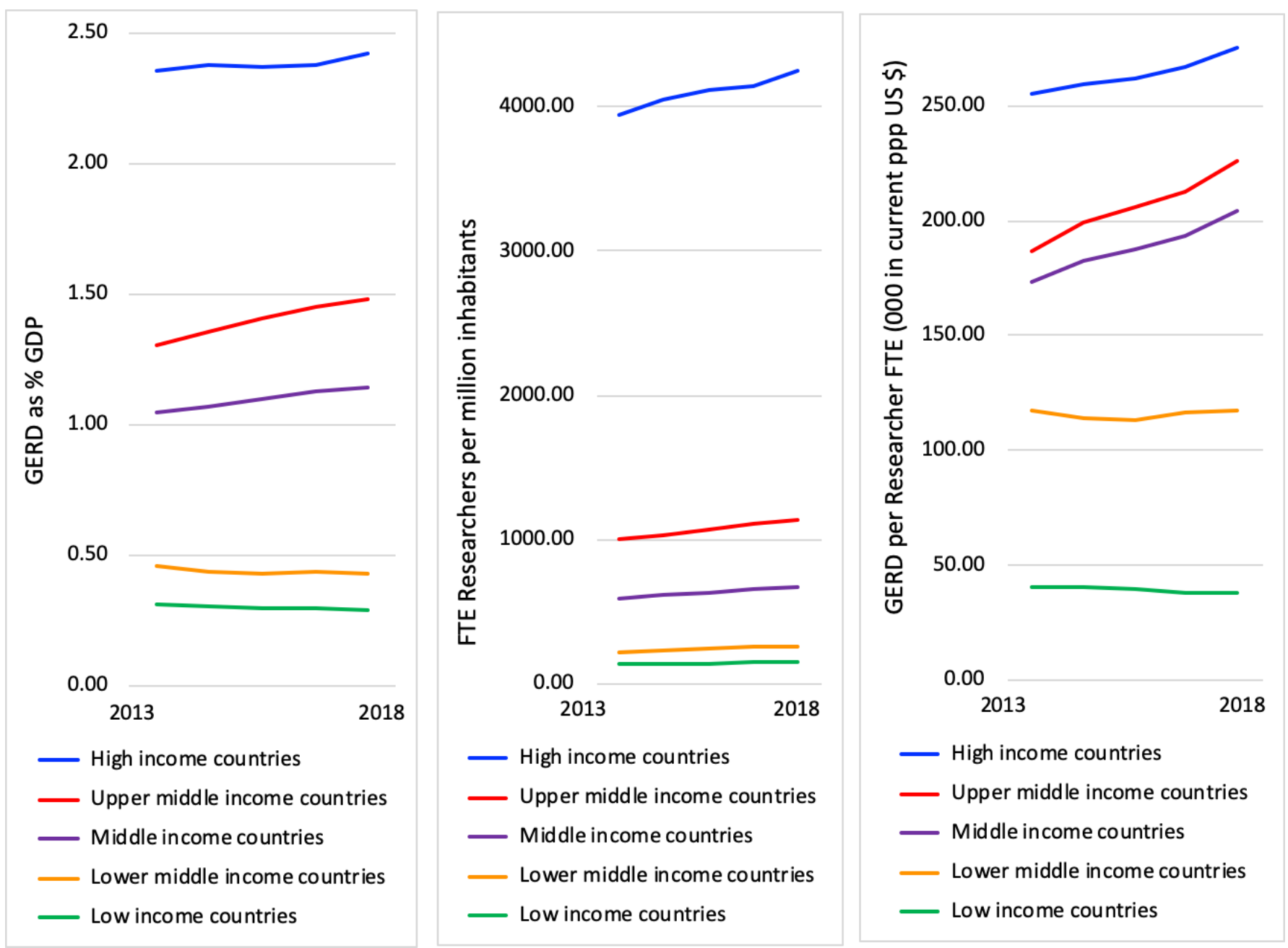

Figure 2. Human and financial resources devoted to R\&D by income worldwide. Change of gross domestic expenditure on R\&D (GERD) as percentage of gross domestic expenditure (GDP) (left), number of full-time equivalent (FTE) researchers per million inhabitants (middle), and GERD per FTE researcher (right) from 2013-2017 in high-, upper middle-, middle-, lower middle-, and low-income countries. Researchers per million inhabitants have increased for all countries, but GERD as a percentage of GDP and GERD per researcher has only increased for middle- to high-income countries. GERD includes expenditure on research and development by business enterprises, higher education institutions, as well as government and private non-profit organizations. For GERD per researcher (middle), costs in local currency units were converted to international dollars using purchasing power parity exchange rates. Data source: UNESCO Institute for Statistics (http://uis.unesco.org/en/news/rd-data-release).

Writing research grants requires a significant amount of time, which for scientists is a valuable and limited commodity (Laudel 2006b; 2014; Sinkjær 2018). In an environment where only a small subset of grant proposals is funded, this large time requirement can unfairly disadvantage certain demographics. For ECRs, it takes them away from the bench at a stage in their career when performing research is vital for establishing themselves. For underrepresented groups such as women and people of color, who often already contribute more of their time towards academic service, it leaves them less time for work that can contribute to tenure and promotion (Gross and Bergstrom 2019; Elise S Brezis 2007). In addition, reviewers often focus on limited metrics of past research success, which do not necessarily provide a good indication of future success. This is especially true for ECRs who lack substantial research history; the Matthew effect, defined as the rich getting richer and the poor getting poorer (Laudel 2006b; Bol and van de Rijt 2018), is unfortunately a great indicator of future funding capability. 
Implementing changes to promote a fairer distribution of funding is necessary to improve career prospects and to drive excellence in scientific research. We, a global group of ECRs, reviewed ECR funding opportunities to better understand international funding practices. We have identified a series of factors that potentially impede equitable and inclusive allocation of research funding. Here, we discuss various aspects of the academic funding systems that impact ECRs and provide recommendations for funding agencies and grant reviewers to implement changes to promote inclusive practices for funding distribution that will benefit ECRs worldwide.

\section{Funding priorities}

Funding should be strategized for both the short- and long-term needs of researchers and the research enterprise. Here, we define short-term need as requiring a specific instrument or funding for a project/individual for one year or less. Long-term need is defined as sustained funding over a three-tofive-year period, with the goal of renewal. Prioritizing financial mechanisms, grant review, and funding recommendations relative to current grant status is key to ensuring equitable opportunities for ECRs. Furthermore, funding agencies categorize research proposals into fundamental and applied research areas, with the balance tipping in recent years toward more funding for applied research. However, fundamental research has great potential to enable long-term advances in technology and wider societal benefits. It serves as the foundation for applied research. Hence, it is essential to improve funding mechanisms for fundamental research ("Research Funding: The Problem with Priorities" 2003).

\section{i. Evaluate the applications on the basis of need}

The Matthew effect is rife in scientific research funding (Table S1a, example 1) (Laudel 2006b; 2014). For example, in $2010,40 \%$ of NIH grant money was held by $10 \%$ of PIs. At the institution level, $80 \%$ of grants were held by $10 \%$ of universities in the US (Wahls 2019). Yet, multiple studies suggest that review panels are not necessarily able to predict future accomplishment. Thus, early success in funding may unfairly tip the balance. To mitigate this, funders may need to monitor the researchers' ongoing awards. The main criteria for judging the potential success of a research proposal are scientific quality, novelty, and feasibility. The competitiveness of research funding may lead to several projects, submitted in the same application round, receiving similar scores for most of these criteria. In such scenarios, funders could mitigate the Matthew effect by funding the applicant or research group most in need of the funds.

Equitable distribution of research funding could be achieved if funders require applicants to disclose whether the proposed research project has received funding from the same or other agencies. This would also apply to overlapping projects. Another requirement would be to distinguish junior and senior research applications by career stage (Table S1b, example 4). However, both solutions come with complications that should be considered. Reducing the unequal competition between more established, likely better funded, PIs and those early in their careers could be accomplished by holding separate funding calls for each group. This solution is easy to implement, but where to place the status cut-off remains unclear. Furthermore, career breaks, such as parental or medical leave, need to be considered. If multiple PIs of different seniority apply together, it could be complicated to determine whose needs or status should be decisive. In this case, funders could ask the applicants to specify the need for collaboration between well-funded and underfunded research groups. Another strategy would be to introduce a more flexible award system so that applicants do not receive the full amount of the research money requested, but rather the amount they are judged to need. We propose that the expert reviewers should advise the grant committee on such allocations. This builds upon the justification for funds which several funding agencies already require. Introducing these measures will also require introducing a transparent declaration of current funding available for the applicant research group as well as clear reviewing guidelines by the funder. Overall, evaluating grant applications on the basis of need would be beneficial to ECRs, who are typically in greater need of research funding than more senior investigators.

\section{ii. Improve funding for fundamental research}

Fundamental research focuses on establishing scientific theories and principles and understanding of natural phenomena that further catalyze long-term progress in STEMM. For example, the understanding of how mRNA works (Karikó et al. 2005) and how 
microbes fight viruses (Mojica and Díez-Villaseñor 2010) were underfunded research avenues but have led to vital discoveries in COVID-19 vaccine production (Newey 2020) and CRISPR technology (The Royal Swedish Academy of Sciences 2020), respectively. While both fundamental and applied research inform each other, the imminent benefits of any fundamental research project cannot be predicted. Despite the increase in the number of researchers worldwide, there has been a significant decline, particularly in low- and middle-income countries, in the availability of funding for fundamental research from both corporations and federally-funded agencies (Powell 2016; "U.S. Research and Development Funding and Performance: Fact Sheet" 2020; Wilke 2018). These trends have resulted in a paucity of funds available for fundamental science (Table S1a, examples 2-3). To alleviate these issues, funders can distribute a designated percentage of funds for fundamental research and limit disproportionate funding by boosting funds to highly specialized applied research areas. Furthermore, stakeholders should allow funding in research areas with insufficient research capacity in order to strengthen the research base of isolated or underappreciated areas. Private and charitable organizations should also be encouraged to invest in fundamental research (Ahmad and Becker 2014). A worldwide call to action is needed for all federal funding agencies to promote discovery and innovation when allocating budgets.

\section{Improvements in the application and review process}

While scientists are skilled at identifying flawed science, they are much less able to differentiate between good and excellent proposals (Danthi et al. 2014; Pier et al. 2018; Klaus 2018; Scheiner et al. 2013; Fang et al. 2016). This discrepancy is due to differences in grant writing styles which may mask significance, lack of clear rubrics or guidelines for ranking of grants, and biases for ones' own research field(s) (Langin 2019). Further, peer review is not a level playing field; it can favor established scientists (Laudel 2006a) and introduce gender and racial biases ("Global State of Peer Review" 2018; Vesper 2018; Klaus 2018; "Is Publishing in the Chemical Sciences Gender Biased?" 2020; Guglielmi 2018; Langin 2019; Witteman et al. 2019). A number of pitfalls, such as disagreement amongst reviewers and persistent biases against certain demographics, have been associated with peer review of funding applications (Pier et al. 2018; Pina et al. 2021; SolansDomènech et al. 2017). Women receive only $39 \%$ of postdoctoral fellowships, and smaller grant funding at the faculty level compared to men (Sheltzer and Smith 2014; Colwell 2020). They also receive less university start-up financial support than men, a factor associated with early-career attrition rates (Sawarkar et al. 2019; Acton et al. 2019). Furthermore, women require 2.5 times the productivity relative to men to receive the same funding level. Meanwhile, African American scientists in the US acquire $50 \%$ fewer NIH grants relative to white scientists (Hoppe et al. 2019; Wennerås and Wold 1997; Taffe and Gilpin 2021). Studies show that nearly $50 \%$ of researchers are unsatisfied with the grant review process, thus highlighting the need for more transparency (Table S1, example 6) (Kuehn 2017; Klaus 2018; Vesper 2018; Gillies 2014).

\section{i. Consider biases}

Grant reviewers and funding committees may hold (un)conscious biases against an applicant (Table 1) ("Research Assessment Practices" 2020). To combat these, reviewers need to recognize that biases influence how they review grant applications and must actively work to minimize these influences. Funders also need to take a firm public stance against biases and provide mandatory training in identifying biases for all their reviewers. Reviewers need to be mindful of the scope of the grant and/or the applicant's skill set. They should ask themselves if they would have the same evaluation and criticisms if the grant application was written by a different (group of) researcher(s). Examples might include applicants from smaller and/or less prestigious institutions or those from minority groups. Reviewers should also avoid making vague criticisms. Being unable to cite specific examples from the grant application to substantiate a criticism may be an indication of biases (Solans-Domènech et al. 2017). Funding agencies should provide grant reviewers with clear guidelines or improve upon their existing guidance, with a view to reducing bias (Box 1). Reviewers can reduce biases using rubrics (Hatch et al. 2019) and performing blinded reviews (see section 2.2). If an open review is conducted, they should publish the internal discussions for transparency (Table S1b, example 5) (Acton et al. 2019; Kuehn 2017; "Research Assessment Practices" 2020). Reviewers can also take steps to minimize 
bias by considering whether under-represented candidates have been subjected to different expectations or standards in order to be considered qualified. Wherever possible, they should ask whether accomplishments, ideas, or findings of under-represented candidates have been unfairly attributed to research directors or collaborators.

Table 1. Possible conscious and unconscious biases grant reviewers may hold against applicants during the grant review process. Bias training course: https://www.chairs-chaires.gc.ca/programprogramme/equity-equite/bias/module-eng.aspx?pedisable=false

\begin{tabular}{|c|c|c|}
\hline Personal biases & Career biases & Family biases \\
\hline Gender identity & Leave/gaps in training & Family Composition \\
\hline Sexual orientation & $\begin{array}{l}\text { Training (lab in which they } \\
\text { are/were trained) }\end{array}$ & $\begin{array}{l}\text { Medical conditions, Maternity or } \\
\text { Parental leaves }\end{array}$ \\
\hline Geographic Region/Country & Career stage & \\
\hline Ethnicity & $\begin{array}{l}\text { Previous publications/ } \\
\text { Grants }\end{array}$ & \\
\hline Language & Educational background & \\
\hline Age & $\begin{array}{l}\text { Prestige (or lack thereof) of the } \\
\text { authors or their institutional } \\
\text { affiliation }\end{array}$ & \\
\hline Race & $\begin{array}{l}\text { Biases based on the model that } \\
\text { the authors support, in fields with } \\
\text { intensely competitive models }\end{array}$ & \\
\hline Nationality & $\begin{array}{l}\text { Interdisciplinary } \\
\text { research/research area }\end{array}$ & \\
\hline $\begin{array}{l}\text { Culture bias including based on } \\
\text { racial, historical, cultural biases } \\
\text { or stereotypes }\end{array}$ & \multirow{3}{*}{$\begin{array}{l}\text { Institutional bias (reputation, } \\
\text { size, type, location, prestige, } \\
\text { affiliation, funds available, } \\
\text { collaboration with other } \\
\text { institutions) }\end{array}$} & \\
\hline Socio-economic status & & \\
\hline Religion & & \\
\hline Ability or Disability & & \\
\hline $\begin{array}{l}\text { Indigenous bias (based on quality, } \\
\text { merit, value, relevance, } \\
\text { importance, success, competence) }\end{array}$ & & \\
\hline
\end{tabular}


Box 1. Guidelines for inclusive grant review. We recommend using the following guidelines to help reviewers reduce bias, thereby generating objective grant reviews. Adapted from (Hainer et al. 2020).

\section{General guidelines to consider when reviewing grant applications}

- Consider any conflict of interest before accepting the grant review invitation.

- Be aware of your implicit biases when reviewing the application.

- Have a standard list of questions with which to review each application.

- Have a standardized rubric with which to score each application.

- Read the application more than once; first for a broad overview, and second for details and an opportunity to reflect back.

- Research small aspects that are unknown to you (e.g., terms or straightforward experiments).

- State clearly which parts of the application you are not qualified to evaluate.

- Perform the review blindly if possible; review the research proposal separate from the CV.

- Allocate sufficient time to review each grant individually.

- Review the document(s) completely, per the grant guidelines.

\section{Reviewing the grant}

- Consider whether the grant application fits the scope of the funding agency and/or this specific grant call.

- Consider whether the proposed experiments answer the research questions/objectives.

\section{Reviewing the CV}

- Take into account the San Francisco Declaration on Research Assessment (sfDORA) (Hatch et al. 2019; Hatch and Curry 2020)

- Consider whether the applicant has the skills, resources and/or collaborations to perform this project.

- Consider what the applicant's research has contributed to the field.

- Take into account career breaks when reviewing the applicant's research output.

- Credit the applicant for travel grants and poster prizes in addition to research funding.

- Take into account contributions to outreach and science communication (e.g., conferences, public engagement).

- Take into account academic service (e.g., mentorship, committee membership).

- Generate separate rubrics for ECRs and established (mid to late career) investigators.

\section{Writing the review}

- Give clear and constructive feedback.

- Consider using gender neutral pronouns (e.g., the applicant, Dr [last name], the team).

- Print the review and read (aloud) to assess.

\section{ii. Blind the review process}

Blinded peer review has been suggested as a mechanism to increase the reviewers' focus on the scientific excellence of a research proposal and enable fairness in funding distribution. Meta-analysis of over 5,000 proposals evaluated in this manner showed that in approximately $20 \%$ of cases, reviewers changed their evaluation after disclosure of applicants' names and publication records (SolansDomènech et al. 2017). However, blinded peer review may be only partially beneficial. Funding agencies may prefer a non-blinded review process to allow for assessment of the infrastructure available at the host institute and of a record of successful employment of previous funds, among others (also discussed in (de Winde et al. 2019)). A completely blinded review may indeed be challenging as proposals typically build upon prior work; hence reviewers may identify who the proposal belongs to, based on the applicant's track record. One alternative is a partially blinded review, where the grant application is evaluated separately from non-research components, such as curriculum vitae (CV). A recent study found that this strategy of science-focused reviews overcame the gender bias seen in traditional grant review (Witteman et al. 2019). This could be implemented by the reviewers (Box 1) or controlled by the funding organization. Once scientific reviews on the research proposal are submitted, granting agencies can share the CV with reviewers for evaluation (Table S1b, example 6). 
iii. Include a preliminary application stage

ECRs planning to apply for career development fellowships face a time-consuming application process. The time from the initial planning and writing of the proposal to the final decision can often take up to 12 months or longer (Kaplan 2012). ECRs in training or at the start of their independent research career are under immense time pressure to demonstrate their ability to obtain funding (also discussed in (de Winde et al. 2019)). Thus, such lengthy evaluation can take a toll on productivity and well-being and it could be career-damaging if the outcome is negative. In some European countries, fellowship and grant application processes consist of multiple stages: submission of a written proposal, sometimes followed by submission of a rebuttal based on reviewer comments, and a final interview round. In contrast, many funding schemes in the US and Canada still depend solely on the initial written proposal.

ECRs would significantly benefit from a preliminary application round in which they submit their CV, a one- to two-page summary of their proposed research, and a letter of support from the host institute or advisor (also discussed in (de Winde et al. 2019)). The result of this first stage should typically be known within one month and should include constructive feedback. If unsuccessful, the applicant can use this feedback to improve the research proposal, build a more competitive CV for the next round, and/or apply for another fellowship (Crow 2020). If successful, the applicant would proceed to write the full research proposal with a degree of certainty that their profile and research ideas fit the call and are likely to be funded. More funding organizations are trialing a preliminary application stage (Table S1b, example 7). An example of such an approach in the US is a letter of intent (LOI) requested from applicants or institutions for certain postdoctoral fellowships and early career PI grant applications (Table S2). An LOI serves to select fewer researchers nationally, by selecting one or few researchers per institution. These who are deemed to be most competitive in the funding call go on to submit a full grant (Table S1b, example 8). We encourage funding bodies worldwide to implement this step. It presents many advantages for ECR applicants, reviewers, and funders by greatly reducing the workload for applicants and reviewers. There would be fewer full grants to review, and short grant proposals are faster to review. Additionally, narrowing the number of contenders with this first round increases the success rate for researchers submitting full proposals. Currently, the success rate for applicants invited to submit a full proposal is $20 \%$ or lower worldwide (Crow 2020). We propose a minimum of $50 \%$ of proposals make it past the first round, to allow in-depth evaluation of all promising ECR applicants and their proposals by expert researchers.

\section{iv. Permit and encourage preprints and other scholarly outputs}

The lengthy peer review and editorial processes involved in publication of research at scientific journals can negatively impact the career development of ECRs (Sarabipour et al. 2019). Publication of a manuscript can take months or years, hindering researchers' ability to apply for academic positions, promotion, grants, and fellowships in a timely manner (Fu et al. 2019; Fraser et al. 2020). Preprints are complete and public drafts of scientific documents, not yet certified by peer review (Abdill and Blekhman 2019). Preprint platforms, such as OSFramework, arXiv, bioRXiv and medRXiv, allow researchers to share findings rapidly and receive feedback prior to submitting their work for peer review (Sever et al. 2019). Preprints are an asset for ECRs in that they decouple dissemination of research output from the peer-review process (Crossley 2015; Fraser et al. 2020). This enables ECRs, who are generally on short contracts, to publicly showcase their scientific work before the time-consuming process of peer-reviewed publication.

Increasingly, funders in the US and Europe are recognizing preprints as academic output (Table $\mathrm{S} 1 \mathrm{~b}$, example 9) ("ASAPBio-Funder Policies" 2018; "Human Frontier Science Program-Use of Preprint Servers" 2017; Sever et al. 2019). Since 2017, the NIH has allowed the inclusion of preprints in both grant applications and reports, yet only peer-reviewed publications are taken into account for funding evaluation and academic promotion purposes. We encourage all funding agencies to allow, encourage, and consider preprints as well as other scholarly output, such as computer code, protocols and research tools, for assessment at all submission and review stages. Furthermore, we encourage all funding agencies to include non-scientific output, such as public engagement, mentorship, and other 
community services in the evaluation of grant applicants (Hatch et al. 2019). This will promote a more equitable evaluation of ECR grant applications by both reviewers and funders.

\section{v. Encourage ECR co-applicants on grants}

To secure a junior group leader position, postdoctoral researchers are often required to demonstrate skills beyond an excellent publication record (Pickett 2019). They must also display intellectual input in previous work, the ability to develop an independent research plan, to manage staff and resources, and to secure funding (Bloch et al. 2014; Dbouk 2014). Postdoctoral researchers without a fellowship may find it challenging to showcase these skills. Therefore, they might face disadvantages in securing grants to start an independent research group later (Callier and Polka 2015). Those working towards establishing an independent academic position should be named as co-investigators on grants, provided they have contributed or will contribute to the development of the project. This includes generating preliminary data to support the proposed project, intellectually contributing to the proposed work, and, if granted, spending the majority of their time on this project and assuming supervisory responsibilities. In the UK, certain funding bodies now permit postdoctoral researchers to be listed as co-investigators on grants. They consider that evidence of involvement in acquiring research funding when postdocs later apply for independent fellowships (Table S1b, example 10) ("BBSRC Research Grants Guide" 2020). Opportunities for discussion and networking with fellow ECRs and PIs at scientific gatherings can further help initiate coapplication on grants. The experience of grant writing and, if successful, the award on their CV, will greatly benefit the future funding and hiring prospects of ECRs.

\section{Improvements to grant conditions}

While the number of ECR funding opportunities need to increase (Callier and Polka 2015; "AAMRI's Budget Priority: Secure the Future of Australia's next Generation of Talent" 2020), other improvements to grant conditions and requirements can enable fairer distribution of existing funds. Next, we discuss funding policies that address the needs of researchers with parental or caring responsibilities, applicant eligibility criteria, and academic mobility. i. Consider parental leave and other career breaks

An academic career, in theory, allows the flexibility of combining research with parental responsibilities. Researchers can often set their own hours in the lab, and certain tasks or research disciplines can be performed remotely. However, in practice, a scientific career often demands substantial time, in the form of long work hours, meetings, and conferences. This makes a career in academia often incompatible with parental or other caring responsibilities (Ecklund and Lincoln 2011). Female academics are particularly affected, as they often take longer career breaks and typically shoulder more housework and childcare responsibilities (Schiebinger and Gilmartin 2010). This sometimes results in female academics deciding not to return to the lab after a career break (Ogden 2019; Mason et al. 2014). The current system for funding research can reinforce this outcome (Epifanio and Troeger 2019). ECRs may find it difficult to benefit from parental leave policies or take adequate parental leave. The current funding system poses challenges for researchers with a young family. Junior faculty may struggle to take leave due to responsibilities associated with starting and managing a team. Short postdoctoral contracts often put time pressure on establishing a scientific niche and academic independence.

Although postdoctoral researchers in many countries are entitled to paid or unpaid parental leave, not all countries extend contracts to compensate for time lost due to leave. Furthermore, grant holders (this can be the postdocs themselves, or their PIs) find external funding inflexible, as grants usually do not allow a research assistant or technician to be hired to substitute a postdoc on parental leave. Thus, valuable research money and time may be lost during this period. Rules and regulations regarding parental leave for both men and women are improving but are not yet equal since women are still entitled to significantly longer parental leave compared to men in the majority of countries. Furthermore, the length of parental leave varies by country, ranging from no time off to over a year. It may also differ among institutions within the same country (Epifanio and Troeger 2019). In many countries, graduate students are not considered "employed", hence they are not offered leave at all.

In the US, Europe, and Canada, funding bodies have introduced policies to support researchers with 
family responsibilities (Table S1b, example 11) (Ogden 2019). These provide fellowship extensions or supplement research costs that are lost when a postdoc takes parental leave during the grant period and they move the grant end date accordingly (Table S1b, example 12, and Table S2). Furthermore, a few dedicated fellowship schemes exist for researchers who have either taken extended time off for child and/or family care or require a more flexible work pattern, with relaxed restrictions on hours and/or days of work (Table S2). While promising, these initiatives are far from common and only partially address the challenges experienced by researchers with parental duties. We recommend that parental leave be an automatic and complete pause halting the applicant's tenure clock, time after PhD, etc. Funding bodies should automatically extend grants or fellowships by the amount of time taken for parental leave. Furthermore, funds should be provided for hiring temporary staff to continue projects during parental leave. Since leave policies vary between universities, research institutes, and government, we recommend coordination to create uniform guidelines between all stakeholders. Equalizing rules and regulations regarding parental leave and other career breaks, especially for ECRs, will help promote fair funding and equality in science.

\section{ii. Remove time-after-PhD restrictions}

A key eligibility criterion for most fellowships is the number of training years after obtaining a doctoral degree. For example, in Sweden, such a restriction also applies to career progression; researchers are only eligible to apply for an assistant professorship within 5 years of PhD graduation (Payne 2018). Of note, this limit is extended in case of parental or sick leave. These policies regarding eligibility for fellowships or career promotion may help to ensure that ECRs are not outcompeted by more experienced colleagues. Despite the benefit of leaves, time limits do not allow for flexible career paths, such as switching research fields or returning from jobs outside academia (also discussed in (de Winde et al. 2019)). They also overlook the unpredictability of research, resulting in longer than anticipated completion time for some projects. Furthermore, time-after-PhD criteria assume that the speed of career progression reflects the researcher's ability, often without taking into account circumstances such as country-specific differences in $\mathrm{PhD}$ duration and publication requirements, illness, parental or family leave, and military or civil service. This system inevitably promotes ECRs with "streamlined" CVs (meaning those who follow a traditional path with few to no academic career breaks), leaving those pursuing diverse career paths or those who are less familiar with the funding system disadvantaged.

The speed of career progression is not a fair measurement of a researcher's potential or creativity. As stated above, career breaks for caring responsibilities may slow a researcher's progress. Additionally, some scientific fields and study systems progress on alternative timelines. Relaxing the timeafter-PhD criteria would allow reviewers to perform a fairer assessment of an applicant's experience and productivity. The UK Medical Research Council has pioneered removal of time-restriction criteria for fellowship applications (Guest Author 2015). Other funding opportunities are dedicated to support diverse career paths and career breaks (Table S1b, examples 13-15, and Table S2). More fellowships should consider removing the time-restriction criteria and, as such, encourage diverse career paths, bringing new ideas and diverse perspectives into academia and promoting personal well-being.

\section{iii. Expand citizenship criteria to permit funding for international researchers}

Science is a global endeavor and international scholars constitute a significant proportion of the academic workforce in countries with major research output. Over $30 \%$ of the total scientific workforce in the US, Canada, UK, Sweden, Switzerland, and Australia is foreign-born (Franzoni et al. 2012). Among postdoctoral scholars in the US, temporary visa holders outnumber citizens and permanent residents combined ("Survey of Graduate Students and Postdoctorates in Science and Engineering Fall 2017: Citizenship of Graduate Students and Postdoctoral Appointees in Science, Engineering, and Health: 1980-2017" n.d.). However, in most countries, ECR fellowships from federal agencies and private foundations are only available to citizens and permanent residents. This leaves international researchers dependent on funding obtained by their PIs. Hence, international ECRs are ineligible to apply for the majority of national funding resources and never manage to secure independent funding. Such policies decrease the pool of talented applicants and create an unfair bias for career advancement based on nationality. 
International ECRs who lack funding may also find themselves less competitive in obtaining future research funding and may have to abandon their research careers. Agencies with global funding opportunities, such as the Howard Hughes Medical Institute (HHMI), European Commission, and the Human Frontiers Program accept applications from all nationalities. Removing eligibility criteria based on citizenship for federal funding will unequivocally make funding opportunities more inclusive. Furthermore, funding for international scholars needs to increase and constraints must be lifted to promote global mobility and advancement of science (Table S1b, example 16). This can be achieved by facilitating educational exchange programs between governments, expanding funding schemes offered by local governments, and increasing financial contributions by private organizations and scientific societies.

\section{iv. Increase funding for academic mobility}

Traveling to other labs for short- or long-term collaboration and attending scientific conferences are important for career development of and networking for ECRs (McInroy et al. 2018). While regional and national conferences are easier to access, international conferences are not within the reach of many researchers. Nations in North America, Europe, and Asia are power hubs of scientific academic research and also host prominent international conferences. Travel for many, however, requires a visa process for entry that is lengthy, expensive, timeconsuming, and uncertain in outcome (Waruru 2018; Gewin 2019). Many countries require in-person visa interviews at locations which might not be close to many applicants, and international sanctions may lead to visa denials (Bezuidenhout et al. 2019). Furthermore, travel imposes a substantial financial burden on ECRs who often earn a living close to the minimum wage (Malloy 2020; Sarabipour 2020). Travel grants are limited worldwide, and many do not cover visa processing fees, creating a burden for ECRs from countries underrepresented in STEMM or of low- and middle-income status. We recommend that funders include travel grants specifically to defray the cost of visa application, and that they set up schemes for ECR travel funding when they are invited for oral or poster presentations. We also recommend that institutions make advance payments on trainee conference attendance and registration costs (Malloy 2020). Finally, conferences should more often be organized online (Weissgerber et al. 2020; Sarabipour et al. 2020, Sarabipour 2020). Virtual conferences were organized in 2020 across disciplines due to the COVID-19 pandemic, providing new avenues for research presentation and networking, enabling wider access and low-cost or free access to the latest research worldwide. Fully utilizing this new format of conferencing will require improving internet access globally. Funding agencies must support the now much lower costs of making these meetings more inclusive in virtual format.

\section{Create alternative funding schemes}

Traditionally in STEMM fields, research funding is allocated competitively based on peer review of research proposals that have low-risk / high-reward expected outcomes. Applicants establish that they have a clear and obvious path to the goal of their proposed project, which will in turn provide substantial societal benefits. This approach is regarded as the best funding allocation method by most researchers and funders worldwide ("Publons Grant In Review Focus" 2019). However, a growing body of evidence suggests that this system is nonideal and biased. Science is unpredictable, and within that unpredictability lie interesting discoveries. Yet traditional competitive funding models essentially discourage researchers from undertaking risky, innovative research (Laudel 2006a; 2006b; 2014), particularly if researchers have no track record in the proposed research area. Previous work suggests that reviewers should concentrate on the ideas represented in funding applications, rather than the scientists behind those ideas (Payne 2018). We advocate for two alternatives: the high risk/high gain and lottery-based funding schemes.

\section{i. Diversify risk}

The concept of High Innovation/NetGain/Expectations (HINGE) funds was developed to direct money towards riskier science, as funding agencies realize there is a need for innovative research that steps outside the realm of what is already known or predictable (Ecklund and Lincoln 2011; Schiebinger and Gilmartin 2010). While not specifically targeted to increase equity, these funds emphasize ideas rather than track record, and may therefore be more attractive for ECRs (Laudel 2014) and underrepresented individuals (also discussed in (de Winde et al. 2019)). More generally, a diversity of funding mechanisms provides more opportunities for 
diverse research. There are now established examples of funding systems catering to a wide range of risk/reward combinations. Low-risk/low-reward projects fit better with philanthropic or community funding, whereas high-risk/low-reward projects lie in the domain of micropayments and crowd funding, with no expectation (or minimal expectation) of a return on the funder's investment (Box 2).

\begin{tabular}{|c|c|c|c|}
\hline \multicolumn{2}{|l|}{ Box 2. Funding models by risk/reward status } & \multicolumn{2}{|c|}{ Perceived Risk } \\
\cline { 2 - 4 } & & Low & High \\
\hline \multirow{2}{*}{ Perceived Reward } & Low & Community Funding & Crowd Funding \\
\hline
\end{tabular}

Crowd funding is considered as a viable funding alternative for research (Danthi 2014), and represents a funding category in which ECRs and women are more successful in receiving funding (Scheiner 2013). Most funding applications require applicants to include preliminary data supporting their hypothesis, or favor proposals that build upon previous research. HINGE funds lack these requirements and therefore give researchers more freedom of imagination. By embracing the diversity of risk and reward in projects, funders can better capture the potential of science to push beyond established and predictable paths.

\section{ii. Consider a lottery-based funding scheme}

Multiple authors have suggested a so-called lotterybased system as an alternative approach for the distribution of funds (Gross 2019; Brezis 2007; Gillies 2014; Fang 2016). Lottery-based systems typically have an initial round of peer review to filter out applications that do not meet some cut-off criteria. Then they apply a random selection process (i.e., a lottery) among the remaining proposals. Such a system could eliminate the biases that arise from peer review (Gillies 2014; Fang 2016). It might improve the efficiency of research funding by reducing the time researchers spend on improving the quality of their proposals (Gross and Bergstrom 2019). To date, multiple funders have launched pilot projects using lottery schemes (Table S1c, example 17-18) (Gross 2019; Bischler 2012). Given the recent emergence and small number of these initiatives, there is little data to validate whether lottery funding lives up to the expectations. An analysis of the Volkswagen Stiftung lottery program's first year revealed that the randomly assigned proposals showed no biases in terms of research fields or factors such as age or gender ("Give Chance a Chance" 2012). Yet, while some funders are testing a lotterybased system, the biggest barrier to implementing such an approach more broadly might be the buy-in of scientists themselves (Table S1c, example 19-20). Nevertheless, given the potential advantages of a lottery system for creating a fairer funding system, we hope to see more funders setting up pilot programs to test its applicability and validity in a range of funding situations.

\section{Closing remarks and outlook}

The substantial time wasted on failed funding applications can unfairly disadvantage certain groups, such as ECRs and traditionally underrepresented scientists. In order to reduce the burden on both researchers and reviewers, and to increase the fairness of distributed funds, funding should be separated for and equitably targeted to distinct career stages, and fundamental, translational, and clinical research fields ("A Cross-Funder Review of Early-Career Clinical Academics: Enablers and Barriers to Progression" 2015). Accelerating innovation may require moving beyond traditional funding strategies and towards new mechanisms for review and funding prioritization. We encourage research funders to experiment with more optimal and equitable funding practices (Box 3). Review criteria should also include applicants' science communication, mentorship, outreach and advocacy efforts on open science practices, as well as their impact on policy and commitment to improving research culture. This will completely assess the research and researcher, as opposed to limiting the focus to prior funding awards and publication records. We recognize that the COVID-19 pandemic has created financial challenges for funders, and as a result some foundations had to cancel funding calls in 2020. There have been different responses to periods where scientists had to put their research on hold. It is likely there will be further reductions in the number of funding opportunities offered worldwide for 2021 and beyond (Table S1d, example 21-23) (Subbaraman 2020). This calls for an urgent 
refocusing of how research funding, which is now even more limited, should be allocated.

Here, we aim to raise awareness of funding issues and initiate discussions with stakeholders to provide increased and more equitable opportunities for ECRs and underrepresented groups vying for fellowships and research grants worldwide. Together, the findings and suggestions described herein may serve as guidelines to funding organizations, universities, research institutes, and governments as they design and implement policies to ensure researchers have a more equal chance of obtaining research funding and making a successful research career.

\section{Box 3. Recommendations for funding organizations and grant reviewers to improve the current ECR funding} prospects worldwide

\section{Recommendations for Funders}

- Identify monetary need \& distribute more funds in an equitable manner to those who need it.

- Encourage fundamental research.

- $\quad$ Require grant reviewers to undergo training in peer review and biases.

- Provide reviewers with concise guidelines to avoid biases and promote fair review.

- Implement preliminary application round with constructive feedback.

- Consider and encourage all scholarly outputs.

- Make funding timeframes flexible to improve work-life balance.

- Permit automatic career break extensions to applications and awarded grants.

- Make sure funding is inclusive and directed towards international researchers.

- Consider funding research with a diversity of risk, and accept a diversity of awards.

- Provide all good applications with an equal opportunity for funding.

- Report transparently on ECR funding rates.

\section{Recommendations for Reviewers}

- Be aware of biases.

- Evaluate the research proposal and applicant identity separately.

- Consider all scholarly outputs and career trajectory of each applicant.

- Be aware of funding call details and review guidelines.

\section{References}

"A Cross-Funder Review of Early-Career Clinical Academics: Enablers and Barriers to Progression." 2015. A Review led by the Medical Research Council in collaboration with the Academy of Medical Sciences, British Heart Foundation, Cancer Research UK, National Institute for Health Research and Wellcome Trust. https://mrc.ukri.org/documents/pdf/review-ofearly-career-clinical-academics/.

"AAMRI's Budget Priority: Secure the Future of Australia's next Generation of Talent." 2020. Association of Australian Medical Research Institutes. August 3, 2020. https://aamri.org.au/news-events/aamrisbudget-priority-secure-the-future-of-australiasnext-generation-of-talent/.

Abdill, Richard J., and Ran Blekhman. 2019. "Tracking the Popularity and Outcomes of All BioRxiv Preprints." ELife 8: e45133. https://doi.org/10.7554/eLife.45133.001.
Acton, Sophie E., Andrew J.D. Bell, Christopher P. Toseland, and Alison Twelvetrees. 2019. "Research Culture: A Survey of New PIs in the UK." ELife 8: e46827. http://www.doi.org/10.7554/eLife.46827.

Ahmad, Tariq, and Richard C. Becker. 2014. "The Unmet Need for Philanthropic Funding of Early Career Cardiovascular Investigators." Journal of Thrombosis and Thrombolysis 37: 527-31. http://www.doi.org/10.1007/s11239-013-10167.

"ASAPBio-Funder Policies." November 5, 2018. https://asapbio.org/funder-policies.

“BBSRC Research Grants Guide." February 2020. https://bbsrc.ukri.org/documents/grants-guide/.

Besselaar, Peter van den, and Ulf Sandström. 2015. "Early Career Grants, Performance, and Careers: A Study on Predictive Validity of Grant Decisions." Journal of Informetrics 9 (4): 826-38. https://doi.org/10.1016/j.joi.2015.07.011. 
Bezuidenhout, Louise, Ola Karrar, Javier Lezaun, and Andy Nobes. 2019. "Economic Sanctions and Academia: Overlooked Impact and Long-Term Consequences." PLOS ONE 14 (11): e0225277. https://doi.org/10.1371/journal.pone.0225277.

Bischler, Ulrike, Pavel Dutow and Friederike Hepp. 2012. "Experiment! - In Search of Bold Research Ideas." VolkswagenStiftung. November 2012. https://www.volkswagenstiftung.de/en/funding Lour-funding-portfolio-at-a-glance/experiment.

Bloch, Carter, Ebbe Krogh Graversen, and Heidi Skovgaard Pedersen. 2014. "Competitive Research Grants and Their Impact on Career Performance." Minerva 52 (January): 77-96. https://doi.org/10.1007/s11024-014-9247-0.

Bol, Thijs, Mathijs de Vaan and Arnout van de Rijt. 2018. "The Matthew Effect in Science Funding." Proceedings of the National Academy of Sciences of the United States of America 115 (19): 4887-90. https://doi.org/10.1073/pnas.1719557115.

Brezis, Elise S. 2007. "Focal Randomisation: An Optimal Mechanism for the Evaluation of R\&D Projects." Science and Public Policy 34 (10): 691-98. https://doi.org/10.3152/030234207X265394.

Callier, Viviane, and Jessica Polka. 2015. "Fellowships Are the Future." Nature 528 (December): 155-56. https://doi.org/10.1038/nj7580-155a.

Colwell, Rita. 2020. "Women Scientists Have the Evidence About Sexism." The Atlantic, August 30, 2020. https://www.theatlantic.com/ideas/archive/202 0/08/women-scientists-have-evidence-aboutsexism-science/615823/

Christian, Katherine, Carolyn Johnstone, Jo-ann Larkins, Wendy Wright, Michael R. Doran. 2021. "Research Culture: A survey of early-career researchers in Australia." $\quad$ ELife 10: e60613. https://doi.org/10.7554/eLife.60613

Crossley, Merlin. 2015. "The Ins and Outs of Research Grant Funding Committees." The Conversation. October 29, 2015. http://theconversation.com/the-insand-outs-of-research-grant-funding-committees49900.

Crow, James Mitchell. 2020. "What to Do When Your Grant Is Rejected." Nature 578 (7795): 477-79. https://doi.org/10.1038/d41586-020-00455-0.

Daniels, Ronald J. 2015. "A Generation at Risk: Young Investigators and the Future of the Biomedical Workforce." Proceedings of the National Academy of Sciences of the United States of America 112 (2): 313-18. https://doi.org/10.1073/pnas.1418761112.
Danthi, Narasimhan, Colin O. Wu, and Michael Lauer Peibei Shi. 2014. "Percentile Ranking and Citation Impact of a Large Cohort of National Heart, Lung, and Blood Institute-Funded Cardiovascular R01 Grants." Circulation Research 114 (January): 600606.

https://doi.org/10.1161/CIRCRESAHA.114.3026 $\underline{56}$.

Dbouk, Hasehm. 2014. "Show Me the Money-Funding Opportunities for International Graduate Students and Postdocs." American Society for Cell Biology (blog). January 31, 2014. https://www.ascb.org/careers/show-me-themoney-funding-opportunities-for-internationalgraduate-students-and-postdocs/.

Ecklund, Elaine Howard, and Anne E. Lincoln. 2011. "Scientists Want More Children." PLOS ONE 6 (8): e22590.

https://doi.org/10.1371/journal.pone.0022590.

Epifanio, Mariaelisa, and Vera E. Troeger. 2019. "Bargaining over Maternity Pay: Evidence from UK Universities." Journal of Public Policy, May. https://doi.org/10.1017/S0143814X19000059.

Faupel-Badger, Jessica M., David E. Nelson and Grant Izmirlian. 2017. "Career Satisfaction and Perceived Salary Competitiveness among Individuals Who Completed Postdoctoral Research Training in Cancer Prevention." PLOS ONE $12 \quad$ (1): $\quad$ e0169859. https://doi.org/10.1371/journal.pone.0169859.

Fernandes, Jason D., Sarvenaz Sarabipour, Christopher T. Smith, Natalie M. Niemi, Nafisa M. Jadavji, Ariangela J. Kozik, Alex S. Holehouse, et al. 2020. "A Survey-Based Analysis of the Academic Job Market." ELife 9: e54097. https://doi.org/10.7554/eLife.54097.

Ferric C Fang, Anthony Bowen and Arturo Casadevall. 2016. "Research: NIH Peer Review Percentile Scores Are Poorly Predictive of Grant Productivity." ELife 5: e13323. https://doi.org/10.7554/eLife.13323.001.

Ferric C. Fang, Arturo Casadevall. 2016. "Research Funding: The Case for a Modified Lottery." MBio 7 (2): e00422-16. https://doi.org/10.1128/mBio.00422-16.

Franzoni, Chiara, Giuseppe Scellato, and Paula Stephan. 2012. "Foreign-Born Scientists: Mobility Patterns for 16 Countries." Nature Biotechnology 30 (12). https://www.nature.com/articles/nbt.2449.pdf? origin $=$ ppub.

Fraser, Nicholas, Fakhri Momeni, Philip Mayr, and Isabella Peters. 2020. "The Relationship between BioRxiv Preprints, Citations and Altmetrics." Quantitative Science Studies 1 (2): 618-38. https://doi.org/10.1162/qss_a 00043. 
Fu, Darwin Y., Jacob J Hughey. 2019. "Meta-Research: Releasing a Preprint Is Associated with More Attention and Citations for the Peer-Reviewed Article." ELife 8: e52646. https://doi.org/10.7554/eLife.52646.

Gewin, Virginia. 2019. "What Scientists Should Know about Visa Hurdles" 569: 297-99. http://doi.org/10.1038/d41586-019-01428-8.

Gillies, Donald. 2014. "Selecting Applications for Funding: Why Random Choice Is Better than Peer Review." RT. A Journal on Research Policy and Evaluation 2 (1). https://doi.org/10.13130/2282-5398/3834.

"Give Chance a Chance." 2012. VolkswagenStiftung. https://www.volkswagenstiftung.de/en/newspress/funding-stories/give-chance-achance-\%E2\%80\%93-a-lottery-decides-whichdaring-research-ideas-receive-funding.

"Global State of Peer Review." 2018. Publons. https://publons.com/static/Publons-GlobalState-Of-Peer-Review-2018.pdf.

Gross, Kevin, and Carl T. Bergstrom. 2019. "Contest Models Highlight Inherent Inefficiencies of Scientific Funding Competitions." PLoS Biology 17 (1): e3000065.

https://doi.org/10.1371/iournal.pbio.3000065.

Guest Author. 2015. "Science Doesn't Only Need Sprinters." Medical Research Council. March 18, 2015. https://mrc.ukri.org/news/blog/science-doesntonly-need-sprinters/?redirected-from-wordpress.

Guglielmi, Giorgia. 2018. "Gender Bias Goes Away When Grant Reviewers Focus on the Science." Nature 554: 14-15. https://doi.org/10.1038/d41586018-01212-0.

Hainer, Sarah, Charlotte M. de Winde, Babak Momeni, Nick Leigh, and Ashley Albright. 2020. "Guidelines Toward Inclusive Practices in Academics by ELife Community Ambassadors." Open Science Framework. https://osf.io/muk7v/.

Hatch, Anna, and Stephen Curry. 2020. "Research Culture: Changing How We Evaluate Research Is Difficult, but Not Impossible." ELife 9: e58654. https://doi.org/10.7554/eLife.58654.

Hatch, Anna, Veronique Kiermer, Erika Shugart Bernd Pulverer, and Stephen Curry. 2019. "Research Assessment: Reducing Bias in the Evaluation of Researchers." ELife. https://elifesciences.org/insideelife/1fd1018c/research-assessment-reducingbias-in-the-evaluation-of-researchers.

Hoppe, Travis A., Aviva Litovitz, Kristine A. Willis, Rebecca A. Meseroll, Matthew J. Perkins, Ian B. Hutchins, Alison F. Davis, et al. 2019. "Topic Choice Contributes to the Lower Rate of NIH Awards to African-American/Black Scientists." Science Advances 5 (10): eaaw7238. https://doi.org/10.1126/sciadv.aaw7238.
"Human Frontier Science Program-Use of Preprint Servers." 2017. https://www.hfsp.org/Use-of-PreprintServers.

"Is Publishing in the Chemical Sciences Gender Biased?" 2020. Royal Society of Chemistry. https://www.rsc.org/globalassets/04campaigning-outreach/campaigning/gen derbias/gender-bias-report-final.pdf.

Kaplan, Karen. 2012. "Funding: Got to Get a Grant." Nature 482 (7385): 429-31. https://doi.org/10.1038/nj7385-429a.

Karikó, Katalin, Michael Buckstein, Houping Ni, and Drew Weissman. 2005. "Suppression of RNA Recognition by Toll-like Receptors: The Impact of Nucleoside Modification and the Evolutionary Origin of RNA." Immunity 23 (2): 165-75. https://doi.org/10.1016/i.immuni.2005.06.008.

Klaus, Bernd, and David del Álamo. 2018. "Talent Identification at the Limits of Peer Review: An Analysis of the EMBO Postdoctoral Fellowships Selection Process." BioRxiv, December. https://doi.org/10.1101/481655.

Kuehn, Bridget M. 2017. "Peer Review: Rooting out Bias." ELife 6: e32014. http://www.doi.org/10.7554/eLife.32014.

Langin, Katie. 2019. "Scientists' Grant Writing Styles Vary by Gender. That Can Lead to Bias." Science, May. https://doi.org/10.1126/science.caredit.aax9105.

Laudel, Grit. 2006a. “The 'Quality Myth': Promoting and Hindering Conditions for Acquiring Research Funds." Higher Education 52: 375-403. https://doi.org/0.1007/s10734-004-6414-5.

Laudel, Grit. 2006b. "The Art of Getting Funded: How Scientists Adapt to Their Funding Conditions." Science and Public Policy 33 (7): 489-504. https://doi.org/10.3152/147154306781778777.

Laudel, Grit, and Gläser, Jochen. 2014. "Beyond Breakthrough Research: Epistemic Properties of Research and Their Consequences for Research Funding." Research Policy 43 (September): 120416. https://doi.org/10.1016/j.respol.2014.02.006. Malloy, John. 2020. "Stop Making Graduate Students Pay up Front for Conferences." Nature, Career Column. http://www.doi.org/10.1038/d41586-02000421-w.

Mason, Mary Ann, Nicholas H. Wolfinger, and Marc Goulden. 2014. "Reviewed Work: Do Babies Matter? Gender and Family in the Ivory Tower." American Journal of Sociology 120 (3): 988-90. http://www.doi.org/10.1086/678475.

McInroy, Gordon R., Catherine A. Lichten, Becky Ioppolo, Sarah Parks, and Susan Guthrie. 2018. "International Movement and Science: A Survey of Researchers by the Together Science Can Campaign." The Wellcome Trust - Together Science Can-RAND Corporation, 74. https://doi.org/10.7249/RR2690. 
Mojica, Francisco J.M., and César Díez-Villaseñor. 2010. "The On-off Switch of CRISPR Immunity against Phages in Escherichia Coli." Molecular $\begin{array}{lll}\text { Microbiology } & 77 & \text { (6): } 1341-45 .\end{array}$ https://doi.org/10.1111/j.13652958.2010.07326.x.

National Institutes of Health. 2012b. "Postdoctoral Researchers-Facts, Trends, and Gaps." NIH Extramural Nexus (blog). June 29, 2012. https://nexus.od.nih.gov/all/2012/06/29/postd octoral-researchers-facts-trends-and-gaps/.

Newey, Sarah. 2020. “'Redemption': How a Scientist's Unwavering Belief in MRNA Gave the World a Covid-19 Vaccine." The Telegraph. December 2, 2020. https://www.telegraph.co.uk/globalhealth/science-and-disease/redemption-onescientists-unwavering-belief-mrna-gave-world/.

"NIH Grants \& Funding: Early Stage Investigator Policies." $2020 . \quad$ https://grants.nih.gov/policy/earlyinvestigators/index.htm.

Ogden, Lesley Evans. 2019. "Women Who Take Extended Maternity Leave Face a Tougher Return to Work." University Affairs (blog). November 2019. https://www.universityaffairs.ca/features/featur e-article/women-who-take-extended-maternityleave-face-a-tougher-return-to-work/.

Pickett, Christopher L. 2019. "The Increasing Importance of Fellowships and Career Development Awards in the Careers of Early-Stage Biomedical Academic Researchers." PLOS ONE 14 (10): e0223876. https://doi.org/10.1371/journal.pone.0223876.

Pier, Elizabeth L., Markus Brauer, Amarette Filut, Anna Kaatz, Joshua Racklaw, Mitchell J Nathan, Cecilia E. Ford, and Molly Carnes. 2018. "Low Agreement among Reviewers Evaluating the Same NIH Grant Applications." Proceedings of the National Academy of Sciences of the United States of America $\quad 115 \quad$ (12): 2952-57. https://doi.org/10.1073/pnas.1714379115.

Pina, David G., Ivan Buljan, Darko Hren, and Ana Marušić. 2021. "Meta-Research: A Retrospective Analysis of the Peer Review of More than 75,000 Marie Curie Proposals between 2007 and 2018." ELife 10: e59338. https://doi.org/10.7554/eLife.59338.

Polka, Jessica K., Kristin A. Krukenberg and Gary S. McDowell. 2017. "A Call for Transparency in Tracking Student and Postdoc Career Outcomes." Molecular Biology of the Cell 26 (8): 1413-15. https://doi.org/10.1091/mbc.E14-10-1432.

Powell, Kendall. 2016. "Young, Talented and Fed-up: Scientists Tell Their Stories." Nature, New Feature, 538: $\quad$ 446-49. http://www.doi.org/10.1038/538446a.

"Publons Grant In Review Focus." 2019. https://publons.com/static/Grant-Review-inFocus-web.pdf.
Payne, David. 2018. "Postdoctoral Training in Sweden: Too Short to Grow." Nature, January 31, 2018. http://blogs.nature.com/naturejobs/2018/01/3 $1 /$ postdoctoral-training-in-sweden-too-short-togrow/.

"Research Assessment Practices." 2020. Vienna, Austria: Science Europe and Technopolis Group. https://www.scienceeurope.org/ourpriorities/research-assessment/researchassessment-processes.

"Research Funding: The Problem with Priorities." 2003. Nature Materials 2 (639). https://doi.org/10.1038/nmat992.

Rockey, Sally. 2012a. "Age Distribution of NIH Principal Investigators and Medical School Faculty." National Institutes of Health Extramural Nexus (blog). February 13, 2012. https://nexus.od.nih.gov/all/2012/02/13/agedistribution-of-nih-principal-investigators-andmedical-school-faculty/.

Sarabipour, Sarvenaz. 2020. "Research Culture: Virtual Conferences Raise Standards for Accessibility and Interactions." ELife 9: e62668. https://doi.org/10.7554/eLife.62668.

Sarabipour, Sarvenaz, Benjamin Schwessinger, Fiona N. Mumoki, Aneth D. Mwakilili, Aziz Khan, Humberto J. Debat, Pablo J. Saez, and Tomislav Mestrovic. 2020. "Evaluating Features of Scientific Conferences: A Call for Improvements." BioRxiv. https://doi.org/10.1101/2020.04.02.022079.

Sarabipour, Sarvenaz, Humberto J Debat, Steven J Burgess Edward Emmott, and Zach Hensel Benjamin Schwessinger. 2019. "On the Value of Preprints: An Early Career Researcher Perspective." PLoS Biology $17 \quad$ (2): $\quad$ e3000151. https://doi.org/10.1371/journal.pbio.3000151.

Sawarkar, Ritwick, Ruth Scherz-Shouval, Martin S. Denzel, and Juha Saarikangas. 2019. "Chaperoning Junior Faculty." EMBO Reports 20 (1): e47163. https://doi.org/10.15252/embr.201847163.

Scheiner, Samuel M., Lynette M Bouchie. 2013. "The Predictive Power of NSF Reviewers and Panels." Frontiers in Ecology and the Environment, October. https://doi.org/10.1890/13.WB.017.

Schiebinger, Londa, and Shannon K. Gilmartin. 2010. "Housework Is an Academic Issue." American Association of University Professors. https://www.aaup.org/article/houseworkacademic-issue\#.X2fXAtZ7nAJ.

Sever, Richard, Michael Eisen, and John Inglis. 2019. "Plan U: Universal Access to Scientific and Medical Research via Funder Preprint Mandates." PLOS Biology $17 \quad$ (6): $\quad$ e3000273. https://doi.org/10.1371/iournal.pbio.3000273. 
Sever, Richard, Ted Roeder, Samantha Hindle, Linda Sussman, Kevin-John Black, Janet Argentine, Wayne Manos, and John R. Inglis. 2019. "BioRxiv: The Preprint Server for Biology." BioRxiv, November. https://doi.org/10.1101/833400.

Shailes, Sarah. 2017. "Peer Review: To Fund or Not to Fund?" ELife 6: e32015. http://www.doi.org/10.7554/eLife.32015.

Sheltzer, Jason M., and Joan C. Smith. 2014. "Elite Male Faculty in the Life Sciences Employ Fewer Women." Proceedings of the National Academy of Sciences of the United States of America 111 (28): 1010712. https://doi.org/10.1073/pnas.1403334111.

Sinkjær, Thomas. 2018. "Fund Ideas, Not Pedigree, to Find Fresh Insight." Nature, World View, 555: 143. https://doi.org/10.1038/d41586-018-02743-2.

Solans-Domènech, Maite, Imma Guillamón, Ignacio Ferreira-González Aida Ribera, Gaietà PermanyerMiralda Carme Carrion, and Joan M. V. Pons. 2017. "Blinding Applicants in a First-Stage Peer-Review Process of Biomedical Research Grants: An Observational Study." Research Evaluation 26 (3): 181-89. https://doi.org/10.1093/reseval/rvx021.

Subbaraman, Nidhi. 2020. "Sputnik Moment or Budget Breaker: How Will the Pandemic Alter Research Funding?" Nature, Feature, 582 (June): 164-65. http://www.doi.org/10.1038/d41586-02001519-x.

"Survey of Graduate Students and Postdoctorates in Science and Engineering Fall 2017: Citizenship of Graduate Students and Postdoctoral Appointees in Science, Engineering, and Health: 1980-2017." n.d. National Science Foundation. https://ncsesdata.nsf.gov/gradpostdoc/2017/ht $\underline{\mathrm{ml} / \mathrm{gss} 17-\mathrm{dt}-\mathrm{tab} 001-}$

3a.htmlhttps://ncsesdata.nsf.gov/gradpostdoc/2 017/html/gss17-dt-tab001-3a.html.

Taffe, Michael A., and Nicholas W. Gilpin. 2021. "Equity, Diversity and Inclusion: Racial Inequity in Grant Funding from the US National Institutes of Health." ELife 10: e65697. https://doi.org/10.7554/eLife.65697.

Tamblyn, Robyn, Nadyne Girard, and James Hanley Christina J Qian. 2018. "Assessment of Potential Bias in Research Grant Peer Review in Canada." $\begin{array}{llll}\text { CMAJ } & 190 & \text { (16): }\end{array}$ https://doi.org/10.1503/cmaj.170901.

The Royal Swedish Academy of Sciences. 2020. "Press Release: The Nobel Prize in Chemistry 2020." Nobel Prize. October 7, 2020. https://www.nobelprize.org/prizes/chemistry/2 020/press-release/.
"U.S. Research and Development Funding and Performance: Fact Sheet." 2020. United States Congressional Research Service. https://fas.org/sgp/crs/misc/R44307.pdf.

Vesper, Inga. 2018. "Peer Reviewers Unmasked: Largest Global Survey Reveals Trends." Nature, New article, , September. http://www.doi.org/10.1038/d41586-01806602-y.

Waruru, Maina. 2018. "African and Asian Researchers Are Hampered by Visa Problems." Nature, September. https://doi.org/10.1038/d41586-018-06750-1.

Weissgerber, Tracey, Yaw Bediako, Charlotte M. De Winde, Hedyeh Ebrahimi, Florencia Fernández-Chiappe, Vinodh Ilangovan, Devang Mehta, et al. n.d.2020. "Point of View: Mitigating the Impact of Conference and Travel Cancellations on Researchers' Futures." ELife 9: 557032. https://doi.org/10.7554/eLife.57032.

"Wellcome Trust Grant Funding Data Report 2018/19." 2020. United Kingdom: Wellcome Trust. https://wellcome.ac.uk/sites/default/files/grant -funding-data-2018-2019.pdf.

Wennerås, Christine, and Agnes Wold. 1997. "Nepotism and Sexism in Peer-Review." Nature 387: 341-43. https://doi.org/10.1038/387341a0.

Wilke, Carolyn. 2018. "Steep Funding Cuts for Australian Science Announced." The Scientist, December 18, 2018. https://www.the-scientist.com/newsopinion/steep-funding-cuts-for-australianscience-announced-65227.

Winde, Charlotte M. de, Elisa Floriddia, David Eccles, TaiYing Lee, Orsolya Symmons, Freyja Olafsdottir, and Vinodh Ilangovan. 2019. "What Makes Funding Programs Fair?" EcrLife (blog). April 5, 2019. https://ecrlife.org/what-makes-fundingprograms-fair- $2 /$.

Witteman, Holly O., Michael Hendricks, Sharon Straus, and Cara Tannenbaum. 2019. "Are Gender Gaps Due to Evaluations of the Applicant or the Science? A Natural Experiment at a National Funding Agency." The Lancet 393 (10171): 531-40. https://doi.org/10.1016/S0140-6736(18)326114 .

Wright, Charles B., Nathan L. Vanderford. 2017. "What Faculty Hiring Committees Want." Nature Biotechnology 35 (September): 885-87. https://doi.org/10.1038/nbt.3962. 
The authors are a group of early career researchers-PhD students, postdocs and junior PIs - with a global representation. They have all been eLife Community Ambassadors throughout 2018-2020 where they have collaborated on the topic of inclusive funding of early career researchers with this work as end result of their research and discussions.

\section{Acknowledgements}

The authors thank Dr. Orsolya Symmons (University of Pennsylvania, Philadelphia, United States; Max Planck Institute for Biology of Ageing, Cologne, Germany) for significant contribution to the part on lottery-based schemes; Dr. Alan Weids for critical reading of the manuscript; Alexandra Stolyarova (University of California, Los Angeles, United States), Amreen Mughal (University of Vermont, United States), Elisa Floriddia (Karolinska Institute, Sweden), Andy Tay (National University of Singapore, Singapore), Devang Mehta (University of Edmonton, Canada), Carolina Quezada (Universidad Bernardo O'Higgins, Chile), and Julia Riley (Stellenbosch University, South Africa) for valuable input and discussion; and the entire early career researcher community of cohorts 2018-2020 of eLife Community Ambassadors, and those who support them, for supporting this work. S.J.H was supported by the National Institutes of Health grant R35GM133732. N.M.J was supported by the American Heart Association grant 20AIREA35050015. 


\section{Supplementary Tables}

Table S1a. Examples of funding agencies' established practices that are in need of reform.

\begin{tabular}{|c|c|}
\hline Example 1 & $\begin{array}{l}\text { Example of the Matthew effect: the American Chemical Society (ACS) canceled their } \\
\text { normal } 2020 \text { grant cycle, but they are proceeding with a (small) competition to provide } \\
\text { supplemental support to ACS-funded labs. This internal competition, meant to support } \\
\text { collaborations, was for grants that are about } 10 \% \text { the size of a standard ACS Cancer } \\
\text { Research Scholar Grants. This is an example of how the Matthew effect works: Initial } \\
\text { successes accumulate into more funds and opportunities. If someone falls off early } \\
\text { (potentially due to COVID), it can have a significant effect on their careers } \\
\text { (https://www.cancer.org/research/we-fund-cancer-research/apply-research- } \\
\text { grant/grant-types/covid-19-and-2020-acs-grants.html). }\end{array}$ \\
\hline Example 2 & $\begin{array}{l}\text { The National Science Foundation (NSF) budget in the US fell below } 50 \% \text { for fundamental } \\
\text { research. Industries are spending, on average, three times the amount in research and } \\
\text { development (R\&D) compared to US federal agencies. According to } 2016 \text { data, } 63 \% \text { of } \\
\text { R\&D funding went to drug development and improving commercial products. Applied } \\
\text { research received } 20 \% \text { of R\&D funding, while fundamental research, carried out for } \\
\text { pure knowledge and understanding, received only 17\% R\&D budget } \\
\text { (https://www.nsf.gov/statistics/2018/nsf18309/\#definitions\&chp2). }\end{array}$ \\
\hline Example 3 & $\begin{array}{l}\text { In New Zealand, there are very few funding opportunities for ECRs. Of the opportunities } \\
\text { that exist, some do not include salary costs or, if they do, not all of the salary is covered. } \\
\text { For example, Marsden Fast Start typically covers } 30-40 \% \text { of a full-time salary, plus greater } \\
\text { than } 100 \% \text { overhead costs. If one's research costs are higher, the portion for the salary is } \\
\text { lower } \\
\text { (https://www.royalsociety.org.nz/early-career-researcher-forum/ecr-resources/ecrs- } \\
\text { in-aotearoa-safeguarding-and-strengthening-opportunity-after-covid-19/). }\end{array}$ \\
\hline
\end{tabular}

Table S1b. Examples of funding agencies' established practices worthy of emulation.

\begin{tabular}{|l|l} 
Example 4 & The Scientific Research Fund in Flanders, Belgium (FWO), National Institutes of Health
\end{tabular} $(\mathrm{NIH})$ in the US, Canadian Institutes of Health Research (CIHR) in Canada and Dutch Research Foundation (NWO) do not make senior and junior lab heads compete for the same grants.

Example 5 FWO (Belgium) implements a rebuttal phase in some assessment processes, with good perceived results. INFN (Italy) publishes information on the transparency of all internal processes, including research evaluation (https://www.scienceeurope.org/ourpriorities/research-assessment/research-assessment-processes/).

Example $6 \quad$ Since 2001, the Agency for Health Quality and Assessment of Catalonia (AQuAS) requests that reviewers evaluate the same proposals in a blinded and unblinded fashion.

Example $7 \quad$ Examples of funding organisations trialling/implementing a prelimiary application stage: Wellcome Trust (UK), Wings for Life (Individual and Project Research Grants on Spinal Cord Injury), Jacobs Early Career Research Fellowship (Table S2), and the Netherlands Research Foundation (NWO) (Table S2). 


\begin{tabular}{|c|c|}
\hline Example 8 & $\begin{array}{l}\text { Funders such as March of Dimes, Beckman Coulter, and Mallinckrodt Pharmaceuticals } \\
\text { only permit invited institutions to submit one, or sometimes two, applications. }\end{array}$ \\
\hline Example 9 & $\begin{array}{l}\text { In Europe, the Medical Research Council (MRC), Cancer Research UK (CRUK), and } \\
\text { Wellcome Trust, the European Molecular Biology Organization (EMBO), Human } \\
\text { Frontiers Program recognize preprints as academic output and encourage preprints. } \\
\text { The Chan-Zuckerberg Initiative (CZI) and the Michael J.Fox foundation in the US have } \\
\text { mandated posting preprints for all articles resulting from research funded by their } \\
\text { organization: } \\
\text { https://www.hfsp.org/Use-of-Preprint-Servers; } \\
\underline{\text { https://asapbio.org/funder-policies; }} \\
\underline{\text { https://www.michaeljfox.org/publication/michael-j-fox-foundation-parkinsons- }} \\
\text { research-adopts-open-access-publication-policy). }\end{array}$ \\
\hline Example 10 & $\begin{array}{l}\text { In the UK, certain funding bodies, including the Biotechnology and Biological Sciences } \\
\text { Research Council (BBSRC) and Cancer Research UK (CRUK), now permit postdoctoral } \\
\text { researchers to be named as co-investigators on grants. This is considered evidence of } \\
\text { the postdoc's involvement in acquiring research funding when applying for } \\
\text { personal/independent fellowships (https://bbsrc.ukri.org/documents/grants-guide/). }\end{array}$ \\
\hline Example 11 & $\begin{array}{l}\text { The US National Institute of Allergy and Infectious Disease (NIAID) provide Primary } \\
\text { Caregiver Technical Assistance Supplements (PCTAS) to support postdoctoral research } \\
\text { scientists who are taking care of a child or sick family member. They provide additional } \\
\text { funds for NIAID grantees to hire a mid-to-senior level technician to fill in when the } \\
\text { caregiver needs to be away from the lab (https://www.niaid.nih.gov/grants- } \\
\text { contracts/research-supplements\#A4). }\end{array}$ \\
\hline Example 12 & $\begin{array}{l}\text { The EMBO Long-Term Fellowships, HFSP Long-Term and Cross-Disciplinary } \\
\text { Fellowships, and the Netherlands organization for Scientific Research (NWO) provide } \\
\text { fellowship extensions (3-18 months for women, and 3-6 months for men dependent on } \\
\text { the funding body) (Table S2). Similarly, the Wellcome Trust (UK) will supplement } \\
\text { research costs that are lost when a postdoc takes parental leave during the grant period, } \\
\text { and grant end date is moved accordingly } \\
\text { (https://wellcome.ac.uk/funding/guidance/maternity-paternity-adoption-and-shared- } \\
\text { parental-leave). }\end{array}$ \\
\hline Example 13 & $\begin{array}{l}\text { Funding opportunities, including the Sir Henry Wellcome Postdoctoral Fellowship, UK } \\
\text { Research and Innovation (UKRI) Future Leaders Fellowships, and the Leverhulme Early } \\
\text { Career Fellowship also consider certain circumstances of career breaks (Table S2) } \\
\text { (https://wellcome.ac.uk/funding/schemes/sir-henry-wellcome-postdoctoral- } \\
\underline{\text { fellowships; }} \\
\underline{\text { https://www.ukri.org/funding/funding-opportunities/future-leaders-fellowships/). }}\end{array}$ \\
\hline Example 14 & $\begin{array}{l}\text { Since July } 1,2020 \text {, modifications to the eligibility period for prospective applicants with } \\
\text { childcare responsibilities have been in effect by German funders. The submission } \\
\text { deadline for female researchers providing childcare within the eligibility period will be } \\
\text { extended by two years per child. The eligibility period for their male counterparts will } \\
\text { be extended by one year per child. Male researchers who provide childcare beyond the } \\
\text { one-year period can also be eligible for a maximum of two-year extension per child } \\
\text { provided appropriate documentation is given. The eligibility period may be extended for } \\
\text { a maximum of six years in total. }\end{array}$ \\
\hline
\end{tabular}




\begin{tabular}{|c|c|}
\hline Example 15 & $\begin{array}{l}\text { Under the Emmy Noether program, a four-year submission deadline follows receipt of } \\
\text { doctorate. As a rule, proposals may only be submitted within four years after obtaining a } \\
\text { doctoral degree. For licensed applicants from the fields of medicine and psychology, a } \\
\text { maximum of six years applies. The submission deadline for female researchers } \\
\text { providing childcare within the eligibility period will be extended by two years per child. } \\
\text { The deadline for their male counterparts will be extended by one year per child, and no } \\
\text { documentation is necessary. Male researchers providing childcare beyond the one-year } \\
\text { period can also be eligible for a maximum of two-year extension per child provided } \\
\text { appropriate documentation is given. Eligibility period may be extended for a maximum } \\
\text { of six years in total. Children who are under the age of } 12 \text { when the period begins, and } \\
\text { who live permanently in the same household as the applicant, are included. }\end{array}$ \\
\hline Example 16 & $\begin{array}{l}\text { International students will be eligible for all UKRI-funded postgraduate studentships } \\
\text { from the start of the } 2021 / 22 \text { academic year (https://www.ukri.org/news/ukri-funded- } \\
\text { postgraduate-programmes-to-open-to-international-students/). }\end{array}$ \\
\hline \multicolumn{2}{|c|}{ Table S1c. Examples of creating alternative funding schemes. } \\
\hline Example 17 & $\begin{array}{l}\text { In 2016, the Health Research Council of New Zealand, announced that it would select so- } \\
\text { called Explorer grants randomly among those who passed an initial vetting by experts. } \\
\text { Contest models highlight inherent inefficiencies of scientific funding competitions } \\
\text { ( } \underline{\text { https://journals.plos.org/plosbiology/article?id=10.1371/iournal.pbio.3000065; }} \\
\underline{\text { https://ecrlife.org/what-makes-funding-programs-fair-2/). }}\end{array}$ \\
\hline Example 18 & 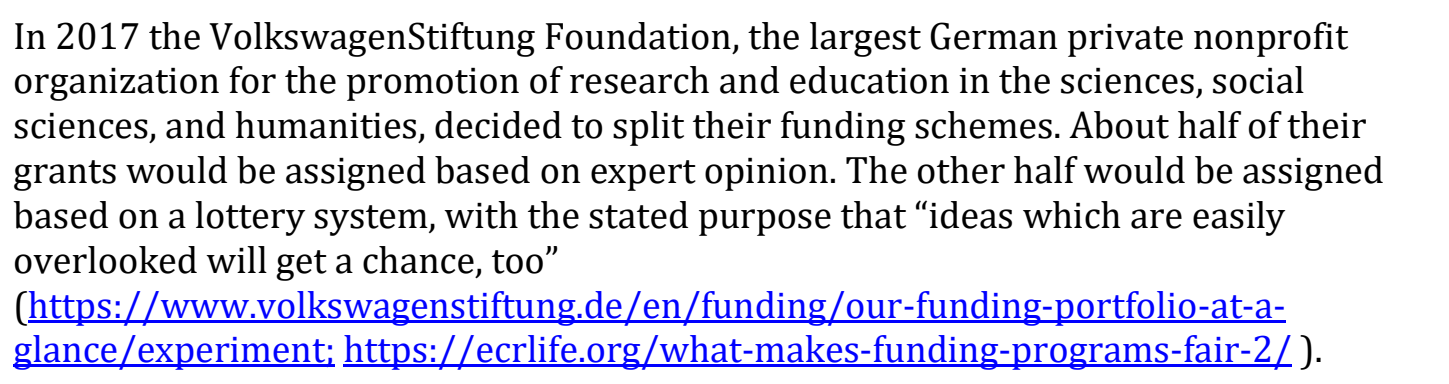 \\
\hline Example 19 & $\begin{array}{l}\text { When the EMBO Fellows program conducted an informal poll on social media in May } \\
2018, \text { the majority of respondents ( } 66 \% \text { of the } 361 \text { votes) supported a lottery system. } \\
\text { The poll also received numerous negative comments and sparked intense debate on } \\
\text { social media. At the time of this publication, no lottery funding schemes have been } \\
\text { implemented. } \\
\text { (https://www.facebook.com/EMBOFellows/posts/935704096610216? th =-R; } \\
\underline{\text { https://ecrlife.org/what-makes-funding-programs-fair- } 2 /) \text {. }}\end{array}$ \\
\hline Example 20 & $\begin{array}{l}\text { A } 2013 \text { survey of Australian researchers found that only } 43 \% \text { supported a lottery for } \\
\text { National Health and Medical Research Council (NHMRC) proposals that were } \\
\text { categorized as "possibly funded" after peer review } \\
\text { (https://eprints.qut.edu.au/107238/1/NHMRC.survey.short.pdf?fbclid=IwAR1K2ArVlQ } \\
\text {-Ae1-PIUcOEh8IS-W1zt2brkNeatnvjdOQQVRHtoBhskSiIas; https://ecrlife.org/what- } \\
\text { makes-funding-programs-fair-2/). }\end{array}$ \\
\hline
\end{tabular}




\begin{tabular}{|l|l|}
\hline Example 21 & $\begin{array}{l}\text { In July 2020, the American Cancer Society (ACS) made the decision to not accept } \\
\text { applications for the October/Fall submission and review cycle for grants that would start } \\
\text { in July 2021. The decision comes as a result of the financial impact of COVID-19. Due to a } \\
\text { significant decrease in donations during COVID-19, ACS will focus on supporting the } \\
\text { applications that have already been reviewed and approved for funding } \\
\text { (https://www.cancer.org/research/we-fund-cancer-research/apply-research- } \\
\text { grant/grant-types/covid-19-and-2020-acs-grants.html). }\end{array}$ \\
\hline Example 22 & $\begin{array}{l}\text { Following consultations with stakeholders, Canadian Institutes of Health Research (CIHR) } \\
\text { will move forward with a plan to temporarily "pause the clock" for all ECRs. Given the } \\
\text { impact of the COVID-19 pandemic on most, if not all, of the CIHR community, this measure } \\
\text { will be applied automatically to all who qualify and will not need to be requested. All those } \\
\text { who held ECR status as of March 1, 2020-or who secured their first academic } \\
\text { appointment after this date-will have their status extended by one year (https://cihr- } \\
\text { irsc.gc.ca/e/52132.html). }\end{array}$ \\
\hline Example 23 & $\begin{array}{l}\text { EMBO, DFG and Marie Curie all informed their fellows about the possibilities to extend } \\
\text { their fellowships due to COVID-19 } \\
\text { (https://www.embo.org/news/articles/2020/coronavirus-update.html; } \\
\text { https://www.dfg.de/en/research funding/corona information/info applicants/index.h } \\
\text { tml\#anker98155350; } \\
\underline{\text { researchers-betrayed-commissions-refusal-extend-costs). }}\end{array}$ \\
\hline
\end{tabular}


Table S2. Funding opportunities referred to in this article by career stage, location and nationality. More funding opportunities can be found on ECRcentral (https://ecrcentral.org), Johns Hopkins University open funding database (https://research.jhu.edu/rdt/funding-opportunities/), University of Nevada Early Career Funding opportunities list (https://www.unr.edu/research-innovation/research-hub/early-career) or Infectious Disease Society of America (IDSA) Funding opportunities list (https://www.idsociety.org/research/research--funding-opportunities/early-career/).

Fellowship schemes that allow scientists to return to academia after a career break

\begin{tabular}{|c|c|c|}
\hline Funding Opportunity & Region/base & Purpose/Description \\
\hline $\begin{array}{l}\text { Marie Curie Career Restart } \\
\text { Panel }\end{array}$ & Europe & $\begin{array}{l}\text { For scientists who have had at least a } 12 \text {-month } \\
\text { career break }\end{array}$ \\
\hline $\begin{array}{l}\text { Christiane Nusslein Volhard } \\
\text { Foundation }\end{array}$ & Germany & $\begin{array}{l}\text { One-year monthly financial grant to pay for } \\
\text { assistance in household chores and for additional } \\
\text { childcare is aimed to relieve young female scientists } \\
\text { from household tasks }\end{array}$ \\
\hline Daphne Jackson Trust & United Kingdom & $\begin{array}{l}\text { To support men and women who wish to return to } \\
\text { science after a career break }\end{array}$ \\
\hline Dorothy Hodgkin Fellowship & United Kingdom & $\begin{array}{l}\text { Early career researcher fellowship for scientists who } \\
\text { require a flexible work pattern (due to childcare } \\
\text { responsibilities, ill health, sick parents etc.) }\end{array}$ \\
\hline $\begin{array}{l}\text { Research Career Re-entry } \\
\underline{\text { Fellowships }}\end{array}$ & United Kingdom & $\begin{array}{l}\text { Fellowship for postdoctoral scientists to re-enter a } \\
\text { research career after a continuous break of at least } \\
\text { two years }\end{array}$ \\
\hline Janet Thornton Fellowship & United Kingdom & $\begin{array}{l}\text { Fellowship from Wellcome Sanger Institute for } \\
\text { postdoctoral scientists who have been on a break for } \\
12 \text { months or more }\end{array}$ \\
\hline \multicolumn{3}{|c|}{ Fellowships for (International) Early Career Researchers based in the US } \\
\hline $\begin{array}{l}\text { Ruth L. Kirschstein National } \\
\text { Research Service Award (NRSA) }\end{array}$ & United States & $\begin{array}{l}\text { Individual Predoctoral Fellowship } \\
\text { (Parent F31) }\end{array}$ \\
\hline $\begin{array}{l}\text { Ruth L. Kirschstein National } \\
\text { Research Service Award (NRSA) }\end{array}$ & United States & $\begin{array}{l}\text { Individual Postdoctoral Fellowship } \\
\text { (Parent F32) }\end{array}$ \\
\hline $\begin{array}{l}\text { Graduate Research Fellowship } \\
\underline{\text { Program }}\end{array}$ & United States & Individual Predoctoral Fellowship (NSF GRFP) \\
\hline $\begin{array}{l}\text { Special Programs for } \\
\underline{\text { Postdoctoral Fellows }}\end{array}$ & United States & Individual Postdoctoral Fellowship \\
\hline
\end{tabular}




\begin{tabular}{|c|c|c|}
\hline $\begin{array}{l}\text { Janelia Graduate Research } \\
\underline{\text { Fellowship }}\end{array}$ & United States & $\begin{array}{l}\text { Individual Predoctoral Fellowship to work in Janelia } \\
\text { for 1-3 years }\end{array}$ \\
\hline Grass Foundation Fellowship & United States & $\begin{array}{l}\text { Individual Fellowship to work at the Marine } \\
\text { Biological Laboratory for } 14 \text { weeks }\end{array}$ \\
\hline$\underline{\text { Hanna H. Gray Fellows Program }}$ & United States & $\begin{array}{l}\text { Transition award to increase diversity in } \\
\text { biomedical sciences; Individual grant for } \\
\text { postdoctoral to early faculty }\end{array}$ \\
\hline $\begin{array}{l}\text { American Association of } \\
\underline{\text { University Women's }} \\
\underline{\text { International Fellowship }} \\
\underline{\text { Program }}\end{array}$ & United States & $\begin{array}{l}\text { Individual award for non-US citizen women } \\
\text { performing predoctoral or postdoctoral research in } \\
\text { US }\end{array}$ \\
\hline $\begin{array}{l}\text { Fulbright Foreign Student } \\
\underline{\text { Program }}\end{array}$ & United States & $\begin{array}{l}\text { Research award to perform research at foreign } \\
\text { institution }\end{array}$ \\
\hline \multicolumn{3}{|c|}{ Pre-doctoral (Graduate) Student Fellowship Opportunities } \\
\hline $\begin{array}{l}\text { American Heart Association } \\
\text { predoctoral Fellowship }\end{array}$ & United States & Individual Predoctoral Fellowship \\
\hline \multicolumn{3}{|c|}{ Postdoctoral Trainee Fellowship Opportunities } \\
\hline$\underline{\text { MSCA Individual Fellowships }}$ & Europe & Individual Postdoctoral Fellowship \\
\hline EMBO Long-Term Fellowships & Europe & Individual Postdoctoral Fellowship \\
\hline $\begin{array}{l}\text { HFSP Long-Term and Cross- } \\
\underline{\text { Disciplinary Fellowships }}\end{array}$ & Europe & Individual Postdoctoral Fellowship \\
\hline Wings for Life & Europe & $\begin{array}{l}\text { Individual and Project Research Grants on Spinal } \\
\text { Cord Injury }\end{array}$ \\
\hline $\begin{array}{l}\text { Flanders Scientific Research } \\
\text { Fund (FWO) }\end{array}$ & $\begin{array}{l}\text { Flanders, } \\
\text { Belgium }\end{array}$ & $\begin{array}{l}\text { Senior and junior lab heads do not compete for the } \\
\text { same grants }\end{array}$ \\
\hline The Emmy Noether Program & Germany & German Research Foundation (DFG) \\
\hline $\begin{array}{l}\text { Dutch Research Foundation } \\
\text { (NWO) }\end{array}$ & The Netherlands & $\begin{array}{l}\text { A preliminary application stage for selected } \\
\text { schemes. Senior and junior lab heads do not } \\
\text { compete for the same grants }\end{array}$ \\
\hline $\begin{array}{l}\text { Jacobs Early Career Research } \\
\underline{\text { Fellowship }}\end{array}$ & Switzerland & $\begin{array}{l}\text { The Jacobs Foundation reviews initial application } \\
\text { before inviting extended application }\end{array}$ \\
\hline $\begin{array}{l}\text { Leverhulme Early Career } \\
\underline{\text { Fellowship }}\end{array}$ & United Kingdom & Individual Fellowship that considers career break \\
\hline Sir Henry Wellcome & United Kingdom & Individual Postdoctoral Fellowship that considers \\
\hline
\end{tabular}




\begin{tabular}{|c|c|c|}
\hline$\underline{\text { Postdoctoral Fellowship }}$ & & career break \\
\hline $\begin{array}{l}\text { American Association for Cancer } \\
\underline{\text { Research (AACR) Postdoctoral }} \\
\underline{\text { Fellowships }}\end{array}$ & United States & $\begin{array}{l}\text { Supports clinical and postdoctoral fellows in the } \\
\text { field of cancer research }\end{array}$ \\
\hline $\begin{array}{l}\text { Arnold } 0 \text { Beckman Postdoctoral } \\
\text { Fellowship }\end{array}$ & United States & $\begin{array}{l}\text { Supports postdoctoral scholars within the core } \\
\text { areas of fundamental chemistry or the development } \\
\text { and build of chemical instrumentation }\end{array}$ \\
\hline $\begin{array}{l}\text { Howard Hughes Medical } \\
\text { Institute (HHMI): International } \\
\text { Postdoctoral Research } \\
\underline{\text { Fellowships }}\end{array}$ & United States & $\begin{array}{l}\text { Provides research funding for outstanding scientists } \\
\text { to advance their careers by working in leading } \\
\text { biomedical laboratories abroad. Fellows work on } \\
\text { interdisciplinary, international teams of scientists, } \\
\text { each of which is led by an HHMI investigator }\end{array}$ \\
\hline Mallinckrodt fellowship & United States & $\begin{array}{l}\text { Invites applications from only one candidate per } \\
\text { biomedical institution }\end{array}$ \\
\hline March of Dimes & United States & $\begin{array}{l}\text { Invites funding proposal of a candidate to be } \\
\text { nominated through institution }\end{array}$ \\
\hline \multicolumn{3}{|c|}{$\begin{array}{l}\text { New Investigator Funding Opportunities } \\
\text { (for Early Career Principal Investigator/Junior Group leader/Tenure track faculty) }\end{array}$} \\
\hline $\begin{array}{l}\text { BBSRC Future Leaders } \\
\underline{\text { Fellowships }}\end{array}$ & United Kingdom & $\begin{array}{l}\text { Supports applicants from diverse career paths, } \\
\text { including those returning from a career break }\end{array}$ \\
\hline $\begin{array}{l}\text { Pew Biomedical Scholars } \\
\text { program }\end{array}$ & United States & $\begin{array}{l}\text { Provides funding to young investigators of } \\
\text { outstanding promise in science relevant to the } \\
\text { advancement of human health. The program makes } \\
\text { grants to selected academic institutions to support } \\
\text { the independent research of outstanding } \\
\text { individuals who are in their first few years of their } \\
\text { appointment at the assistant professor level. }\end{array}$ \\
\hline$\underline{\text { Searle Scholars Program }}$ & United States & $\begin{array}{l}\text { Makes grants to selected universities and research } \\
\text { centers to support the independent research of } \\
\text { exceptional young faculty in the biomedical sciences } \\
\text { and chemistry. }\end{array}$ \\
\hline $\begin{array}{l}\text { The David \& Lucile Packard } \\
\text { Foundation }\end{array}$ & United States & $\begin{array}{l}\text { Invites selected universities to nominate two early- } \\
\text { career professors }\end{array}$ \\
\hline$\underline{\text { Sloan Foundation }}$ & United States & $\begin{array}{l}\text { Reviews letter of inquiry before inviting submission } \\
\text { of grant proposal }\end{array}$ \\
\hline $\begin{array}{l}\underline{\text { University of Massachusetts }} \\
\underline{\text { Database for Early career }} \\
\underline{\text { faculty funding opportunities }}\end{array}$ & United States & $\begin{array}{l}\text { Institutional database and administrative support } \\
\text { on funding opportunities for Early Career Faculty }\end{array}$ \\
\hline
\end{tabular}

